


\title{
PAS Update aanvullende reservemaatregelen Landbouw
}

\author{
K. Groenestein ${ }^{1}$ \\ N. Ogink ${ }^{1}$ \\ H. Ellen ${ }^{1}$ \\ L. Šebek ${ }^{1}$ \\ C. van Bruggen ${ }^{2}$ \\ J. Huijsmans ${ }^{3}$ \\ I. Vermeij ${ }^{1}$ \\ 1 Wageningen Livestock Research \\ 2 CBS \\ 3 Wageningen Plant Research International
}

Dit onderzoek is uitgevoerd door Wageningen Livestock Research, in opdracht van en gefinancierd door het Ministerie van Landbouw, Natuur en Voedselkwaliteit, in het kader van het Beleidsondersteunend onderzoek thema 'Themanaam' (projectnummer KD-2019-042)

Wageningen Livestock Research

Wageningen, december 2019

Rapport 1214 
Groenestein, K., Ogink, N., Ellen, H., Šebek, L., Bruggen, van C., Huijsmans, J. en I. Vermeij, 2019. PAS Update aanvullende reservemaatregelen Landbouw. Wageningen Livestock Research, Rapport 1214.

\section{Samenvatting}

De stikstofdepositie in veel Natura 2000-gebieden in Nederland is hoger dan gewenst. Dit heeft geleid tot een impasse in economische ontwikkeling van onder meer de veehouderij. Voor de drie sectorclusters Verkeer en Vervoer, Industrie en Energie en de Landbouw werden daarom in 2017 bronmaatregelen geïnventariseerd om knelpunten op te vangen. Voor de landbouw is de lijst met maatregelen geupdate in overleg met vertegenwoordigers van de sector, onderzoek en beleid, uitgewerkt en beschreven in onderhavig rapport. Deze studie is uitgevoerd in opdracht van het Ministerie van Landbouw, Natuur en Voedselkwaliteit en tot stand gekomen vóór de uitspraak van de Raad van State aangaande PAS.

\section{Summary}

In many Natura 2000 area's, the nitrogen deposition is higher than wished for. This led to a deadlock in economic development of, among others, livestock husbandry. For the three sector groups Traffic and Transportation, Industry and Energy, and Agriculture source measures were listed in 2017 to deal with the bottlenecks. For agriculture, the list with measures is updated in consultation with representatives of the agricultural sector, research and policy, developed and written in this present report. This study was performed by order of the Ministry of Agriculture, Nature and Food quality before the Council of State made judgement regarding PAS.

Dit rapport is gratis te downloaden op https://doi.org/10.18174/507036 of op www.wur.nl/livestock-research (onder Wageningen Livestock Research publicaties).

\section{(C) 2019 Wageningen Livestock Research}

Postbus 338, 6700 AH Wageningen, T 03174839 53, E info.livestockresearch@wur.nl, www.wur.nl/livestock-research. Wageningen Livestock Research is onderdeel van Wageningen University \& Research.

Wageningen Livestock Research aanvaardt geen aansprakelijkheid voor eventuele schade voortvloeiend uit het gebruik van de resultaten van dit onderzoek of de toepassing van de adviezen.

Alle rechten voorbehouden. Niets uit deze uitgave mag worden vermenigvuldigd en/of openbaar gemaakt worden door middel van druk, fotokopie, microfilm of op welke wijze dan ook zonder voorafgaande toestemming van de uitgever of auteur.

Wageningen Livestock Research is NEN-EN-ISO 9001:2015 gecertificeerd.

Op al onze onderzoeksopdrachten zijn de Algemene Voorwaarden van de Animal Sciences Group van toepassing. Deze zijn gedeponeerd bij de Arrondissementsrechtbank Zwolle. 


\section{Inhoud}

$\begin{array}{ll}\text { Inleiding } & 5\end{array}$

$\begin{array}{ll}\text { Factsheets Maatregelen } & 6\end{array}$

$\begin{array}{ll}\text { Huisvestingsmaatregelen } & 7\end{array}$

$\begin{array}{lll}3.1 & \text { Pluimvee } & 7\end{array}$

3.1.1 Factsheet 1. Dagontmesting met mestbandsystemen 7

3.1.2 Factsheet 2. By-pass van luchtwasser 8

$\begin{array}{ll}3.2 \text { Rundvee } & 10\end{array}$

3.2.1 Factsheet 3a. Introductie mestschuiven in stallen met roostervloer zonder $\begin{array}{ll}\text { mestschuif } & 10\end{array}$

3.2.2 Factsheet 3b. Spoelen vloer en verdunnen mest in stallen met roostervloer

3.2.3 Factsheet 4. Ventilatiemanagement gericht op beperkt debiet 13

3.2.4 Factsheet 5. Luchtzuivering in de nok 14

3.2.5 Factsheet 6. Luchtzuivering van lucht uit de kelder 16

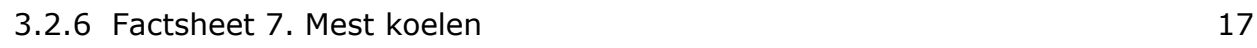

3.2.7 Factsheet 8a. Frequent mest verwijderen uit de stal zonder mestopslag $\begin{array}{ll}\text { onder de vloer in nieuwe stallen } & 18\end{array}$

3.2.8 Factsheet $8 \mathrm{~b}$. Frequent mest verwijderen uit de stal zonder mestopslag $\begin{array}{ll}\text { onder de vloer in bestaande stallen } & 20\end{array}$

4

$\begin{array}{ll}\text { Voermaatregelen } & 22\end{array}$

$\begin{array}{lll}4.1 & \text { Rundvee } & 22\end{array}$

4.1.1 Factsheet 9. TAN-excretie melkvee verminderen via voerspoor $\quad 22$

5

$\begin{array}{ll}\text { Toediening } & 24\end{array}$

$\begin{array}{lll}5.1 & \text { Algemeen } & 24\end{array}$

5.1.1 Factsheet 10. Verbeteren van effectiviteit van toedieningstechnieken $\quad 24$

5.1.2 Factsheet 11. Emissiebeperkende weersomstandigheden 26

Bijlage 1 Referentiesystemen t.b.v. behoeve van ammoniakemissie-reductie berekening van Facsheet 1: Dagontmesting met mestbandsystemen

Bijlage 2 Achtergrondinformatie bij Factsheet 9: TAN-excretie verminderen op het melkveebedrijf met voermaatregelen 



\section{$1 \quad$ Inleiding}

Rond Natura 2000-gebieden die zwaar met stikstof zijn belast, werden op grond van de Natuurbeschermingswet $1998^{1}$ nauwelijks nog nieuwe vergunningen verleend voor activiteiten die leiden tot een toename van de depositie van stikstof in voor stikstof gevoelige habitats in Natura 2000-gebieden. De stikstofdepositie is namelijk in veel gevallen hoger dan voor de natuurdoelen als gewenst wordt beschouwd. Dit heeft geleid tot een impasse in economische ontwikkeling van onder meer de veehouderij.

Door de PAS-partners is afgesproken een breed reservepakket te ontwikkelen met maatregelen die generiek of lokaal inzetbaar zijn om emissies van stikstofverbindingen te reduceren.

Het Ministerie van Economische Zaken (EZ) had samen met het Ministerie van Infrastructuur en Milieu (IenM) en het Interprovinciaal Overleg (IPO) een traject uit gezet waarin voor 3 clusters van sectoren werd geïnventariseerd welke bronmaatregelen in beeld konden komen voor opname in dit reservepakket. Dit betreft de volgende sectorclusters: Verkeer en Vervoer, Industrie en Energie en de Landbouw. Voor de landbouwsector had de WUR deze inventarisatie uitgevoerd op basis van expertmeetings met vertegenwoordigers van betreffende relevante sectoren en vastgelegd in een rapport (Groenestein etal., 2017).

$\mathrm{Nu}$, ruim twee jaar verder was behoefte aan een update van de landbouwmaatregelen. Wederom zijn, in overleg met beleid, onderzoek en sectorvertegenwoordigers, bestaande kennis en expertinzichten bij elkaar gebracht op het gebied van NH3-emissiereducerende maatregelen. De maatregelen worden beoordeeld op de volgende criteria:

- $\quad$ kosten en kosteneffectiviteit;

- $\quad$ tijdpad van implementatie

- afdwingbaarheid en instrumentatie;

- draagvlak bij sector: welke technische belemmeringen zijn te voorzien en of stimuleringsmaatregelen nodig zijn.

Deze rapportage is tot stand gekomen vóór de uitspraak van de Raad van State aangaande PAS.

\footnotetext{
${ }^{1}$ Per 1-1-2017 is de Natuurbeschermingswet 1998 opgegaan in de Wet natuurbescherming.
} 


\section{Factsheets Maatregelen}

De volgende paragrafen bevatten factsheets met een beschrijving van maatregelen die generiek inzetbaar zijn om ammoniakemissie uit de landbouw te reduceren. De selectie bestaat uit door het ministerie van LNV geprioriteerde maatregelen op basis van overleg met de sector en deskundigen en is gebaseerd op de technische mogelijkheid van de maatregel nu of in de nabije toekomst. Of technologische mogelijkheden ook ten volle zullen worden ingezet door de sector wordt niet besproken, omdat daar geen kwantitatieve gegevens aan gekoppeld kunnen worden. Wel wordt kwalitatief aangegeven of het gewenst is stimuleringsmaatregelen toe te passen om een maatregel ten volle te benutten. De voermaatregel bijvoorbeeld, zit op de grens van wat met de huidige inzichten technisch mogelijk is. De vraag of boeren daadwerkelijk op het scherpst van de snede gaan voeren, wordt in dit rapport niet beantwoord. De beschrijving van de maatregel geeft ook de context aan waarbinnen die moet of kan worden toegepast. Dit kan bijvoorbeeld van belang zijn om te voorkomen dat andere ongewenste gassen kunnen ontstaan of dat productieresultaten onder de maatregel zouden kunnen lijden.

De emissiedaling op nationale schaal is met het Nationaal Emissiemodel Agriculture (NEMA) berekend in kton $\mathrm{N} / \mathrm{jaar}$ door de hele mestketen heen. Dat betekent dat wanneer een emissiereducerende maatregel in de stal tot gevolg heeft dat meer $\mathrm{N}$ in de mest achterblijft, een deel van deze winst verloren gaat tijdens opslag en bij het uitrijden van de mest. Dit is verdisconteerd in de berekeningen. Tevens is berekend wat het effect zou zijn bij $100 \%$ implementatie, of wanneer alle traditionele stallen zouden worden ingericht (bv A1.100 voor melkvee) wanneer dit technisch mogelijk is. Wanneer maatregelen alleen in nieuwbouw gerealiseerd kunnen worden is dat in 2030 niet haalbaar met een vernieuwingspercentage van $4 \%$ per jaar.

De kosteneffectiviteit is berekend door de jaarkosten van een maatregel te delen door de emissiedaling uitgedrukt in kton $\mathrm{N} / \mathrm{jaar}$. De jaarkosten zijn inclusief de jaarlijkse afschrijving van de investering die ook is opgenomen in de factsheet.

De tijdgebondenheid die in de factsheets wordt gegeven is enkel gebaseerd op technische mogelijkheden of beperkingen gegeven de huidige markt. Wanneer er bijvoorbeeld maar één aanbieder is kan de levering van een systeem beperkend zijn voor de invoeringssnelheid van de maatregel. Hoe de markt zich in de toekomst kan ontwikkelen afhankelijk van patenten en juridische eigendommen is niet meegenomen. Een ander voorbeeld is wanneer nieuwbouw vereist is voor een maatregel. Dan wordt gesteld dat de afschrijving van een gebouw 25 jaar is. Dat betekent dat per jaar $4 \%$ van de stallen vervangen worden.

De huisvestingsmaatregelen zijn op het moment van deze rapportage niet opgenomen in de Regeling ammoniak en veehouderij (Rav) in het kader van het Besluit Emissiearme Huisvesting (BEH). Mogelijk dat dat in de toekomst wel gebeurt. De voedingsmaatregelen betroffen in de eerdere studie varkens, pluimvee en melkvee. Deze studie beperkt zich tot voeding voor melkvee. De toedieningsmaatregelen behelzen verbetering van effectiviteit van bestaande technieken en het toedienen van mest tijdens gunstige weersomstandigheden.

Per factsheet wordt een korte toelichting en onderbouwing gegeven. Bij een uitgebreide technische onderbouwing wordt verwezen naar een bijlage. De toelichting per factsheet behelst de maatregel zelf, aspecten rondom praktische implementatie en de kostenberekening.

T.a.v. de afdwingbaarheid en instrumentatie is de beoordeling op technische gronden gebaseerd, waarbij gebruik is gemaakt van de kennis van de sector en haar bedrijfseconomische afwegingen. Sociaal maatschappelijke of beleidsmatige argumenten zijn niet meegenomen. 


\section{Huisvestingsmaatregelen}

\subsection{Pluimvee}

\subsubsection{Factsheet 1. Dagontmesting met mestbandsystemen}

\section{Dagontmesting met mestbandsystemen i.c.m. een droogtunnel in pluimveestallen}

Dit systeem is toepasbaar voor pluimveestallen met mestbandsystemen: kooi- en volièresystemen voor leghennen (E 2) en opfokleghennen (E 1)

Deze maatregel kent geen droging in de stal, binnen 24 uur wordt de mest via banden afgedraaid en in de droogtunnel gebracht. Daar wordt de mest gedroogd tot minimaal $80 \%$ drogestof.

\begin{tabular}{|c|c|}
\hline & 2030 \\
\hline $\begin{array}{l}\text { Bij landelijke maatregelen: emissiedaling (kton } \\
\mathrm{N} / \mathrm{jr} \text { ) }\end{array}$ & 1,4 \\
\hline $\begin{array}{l}\text { Implementatie } \\
\text { (kosteneffectiviteit en tijdpad) }\end{array}$ & 2030 \\
\hline Kosteneffectiviteit (M€/kton $\mathrm{N}$ ) & 9,1 \\
\hline Investeringskosten voor de sector ( $\mathrm{mln} €$ ) & 92 \\
\hline Operationele kosten voor de sector ( $\mathrm{m} \ln € / \mathrm{jr}$ ) & 12,8 \\
\hline Tijd benodigd voor invoering maatregel (jr) & $\begin{array}{l}\text { Afhankelijk van uitgangssituatie en } \\
\text { type pluimvee (Zie Bijlage } 1 \text { ) }\end{array}$ \\
\hline Termijn waarop effect wordt bereikt (jr) & Direct effect bij implementatie \\
\hline \multicolumn{2}{|l|}{ Afdwingbaarheid en instrumentatie } \\
\hline $\begin{array}{l}\text { Verplicht in te voeren via wet- en regelgeving } \\
\text { (ja/nee) }\end{array}$ & $\mathrm{Ja}$ \\
\hline $\begin{array}{l}\text { Vrijwillig in te voeren via kennisdeling en } \\
\text { stimulering ( } j a / n e e)\end{array}$ & $\begin{array}{l}\text { Ja en Nee. De verwachting is dat de } \\
\text { ontwikkeling tot } 2025 \text { autonoom en o.i.v. } \\
\text { Besluit emissiearme huisvesting plaats zal } \\
\text { vinden. Voor ontwikkeling na } 2025 \text { wordt } \\
\text { verwacht dat een stimuleringsregeling nodig } \\
\text { zal zijn. }\end{array}$ \\
\hline Vrijwillige afspraak (ja/nee) & $\begin{array}{l}\text { Afhankelijk van de afzetbaarheid van de } \\
\text { mest. }\end{array}$ \\
\hline
\end{tabular}

\section{Toelichting maatregel}

In Bijlage 1 wordt nader ingegaan op de stalsystemen die als referentie dienen en de huidige en toekomstige implementatie van de afzonderlijke referentiesystemen en maatregelen voor volière, kooi- en grondhuisvesting. Deze maatregel vereist een droogtunnel als nageschakelde techniek. De emissiereductie in de stal wordt dus deels teniet gedaan door de extra emissie die ingerekend wordt voor de droogtunnel ( type E 6.4 in de Rav) met een additionele emissie van 0.001 en $0.002 \mathrm{~kg} / \mathrm{jaar}$ per dierplaats voor respectievelijk opfokleghennen en leghennen.

De huidige emissiefactoren in de Rav zijn voor de droogtunnels en de volièresystemen te laag (Ellen etal., 2017). Betere cijfers zijn echter nog niet voorhanden. De berekende reducties zijn daarom onderschattingen van de werkelijke reducties. Echter, om tot een gewenst emissieniveau te komen moeten de hogere emissies van pluimvee ook weer door de PAS gecompenseerd worden. Daarom hanteren we toch de beschikbare (te lage) emissiefactoren in de huidige Rav. 


\section{Toelichting praktische implementatie}

Ca 30\% van de (opfok)leghennen zit in 2017 nog op grondhuisvesting. Deze zullen niet omschakelen naar dagontmesting. Enerzijds omdat ze geen mestband hebben (op E 2.12.1 na), anderzijds is de verwachting dat boeren met grondhuisvesting bij noodzaak van investeren om zullen schakelen naar volièrehuisvesting.

Het drogen in de droogtunnel is een continu proces, want de mest moet binnen 24 uur droog genoeg zijn om te voorkomen dat de urinezuur in de mest wordt omgezet in ammoniak.

\section{Toelichting kosten}

Bij 75\% van de dieren moeten tot 2030 nog droogtunnels gebouwd worden, waarvan $25 \%$ reeds in 2025 (Bijlage 1). Er wordt vanuit gegaan dat per 45.000 dieren (gemiddelde bedrijfsgrootte) één droogtunnel geplaatst wordt. De investering van een droogtunnel bedraagt $€ 3,36$ per opfokhen en $€$ 4,20 per leghen. Tot 2025 voor $30 \%$ van de opfokhennen en $25 \%$ van de leghennen. In 2018 waren er 11,3 miljoen opfokhennen en 34 miljoen leghennen in Nederland. Investering tot 2025 is dan $30 \% * 3,36 * 11,3$ miljoen $+25 \% * 4,20 * 34$ miljoen is $€ 47$ miljoen. Tot 2030 is de investering $55 \% * 3,36 * 11,3$ miljoen $+50 \% * 4,20 * 34$ miljoen is $€ 92$ miljoen.

Jaarkosten tot 2025 zijn dan $30 \% * 0,47 * 11,3$ miljoen $+25 \% * 0,58 * 34$ miljoen is $€ 6,5$ miljoen. Tot 2030 zijn de jaarkosten $55 \% * 0,47 * 11,3$ miljoen $+50 \% * 0,58 * 34$ miljoen is $€ 12,8$ miljoen. Operationele kosten van de droogtunnel zijn de versnelde afschrijving, rente, dagelijkse energiekosten: $300 \mathrm{MJ} / 1000$ eieren (Ellen, mondelinge mededeling) en onderhoud.

\subsubsection{Factsheet 2. By-pass van luchtwasser}

\section{Toepassing gedeeltelijke luchtzuivering in vleeskuikenstallen}

De maatregel behelst het toepassen van behandeling van een deel van de afgevoerde ventilatielucht met daarnaast een onbehandelde bypass-stroom.

Wanneer de luchtwasser gedimensioneerd wordt op $50 \%$ van de maximale ventilatiecapaciteit zal slechts $15 \%$ van de lucht onbehandeld de stal verlaten. Met een chemische luchtwasser die $90 \%$ van de ammoniak uit de lucht kan verwijderen, wordt dan in totaal $75 \%$ ammoniakemissie gereduceerd.

\begin{tabular}{|c|c|}
\hline Effectiviteit reductie & 2030 \\
\hline $\begin{array}{l}\text { Bij landelijke maatregelen: emissiedaling (kton } \\
\mathrm{N} / \mathrm{jr} \text { ) }\end{array}$ & 0,8 \\
\hline $\begin{array}{l}\text { Implementatie } \\
\text { (kosteneffectiviteit en tijdpad) }\end{array}$ & 2030 \\
\hline Kosteneffectiviteit $(€ /$ kton $N)$ & 33 \\
\hline Investeringskosten voor de sector $(\mathrm{M} €)$ & 88 \\
\hline Operationele kosten voor de sector ( $\mathrm{M} € / \mathrm{jr}$ ) & 26,5 \\
\hline Tijd benodigd voor invoering maatregel (jr) & Vanaf 2020 \\
\hline Termijn waarop effect wordt bereikt (jr) & $100 \%$ in 2030 \\
\hline $\begin{array}{l}\text { Verplicht in te voeren via wet- en regelgeving } \\
\text { (ja/nee) }\end{array}$ & Ja, kan in bijlage 1 van de Rav \\
\hline $\begin{array}{l}\text { Vrijwillig in te voeren via kennisdeling en } \\
\text { stimulering ( } \mathrm{ja} / \mathrm{nee})\end{array}$ & $\begin{array}{l}\text { Ja, stimulering kan leiden tot verhoging } \\
\text { implementatieniveau }\end{array}$ \\
\hline Vrijwillige afspraak (ja/nee) & Nee \\
\hline
\end{tabular}




\section{Toelichting maatregel}

Luchtzuiveringstechnieken voor stallen die zijn opgenomen op de Rav-lijst kennen als eis dat zij worden gedimensioneerd op het maximale ventilatie-volume van de stal. Het toepassen van behandeling van een deelstroom met daarnaast een onbehandelde bypass-stroom is tot dusver niet toegestaan uit oogpunt van handhaving. Dit maakt de toepassing van luchtzuivering relatief duur in vleeskuikenstallen met maximale ventilatie-niveaus die slechts een zeer beperkt deel van het jaar voorkomen. Uit berekeningen blijkt dat bij een dimensionering van een wasser afgestemd op $50 \%$ van de maximale ventilatiecapaciteit, slechts $15 \%$ van de ammoniakemissie via de bypass ongezuiverd hoeft te blijven. De huidige verplichte elektronische monitoring van luchtwassers maakt het mogelijk de belasting van de luchtwasser en de volumestroom van het onbehandelde bypass-deel goed vast te leggen. Deelbehandeling van de ventilatielucht is daardoor goed handhaafbaar.

De maatregel bestaat uit:

- het installeren van een chemische/gecombineerde luchtwasser die wordt gedimensioneerd op $50 \%$ van de maximaal benodigde ventilatiecapaciteit, en een bypass voor de overige ventilatielucht. De netto-stalreductie van de ammoniakemissie bedraagt $75 \%$.

Reductie-effect: bij dimensionering van de luchtwasser op 50\% van het maximum-ventilatieniveau wordt $85 \%$ van de totale ammoniakemissie door de wasser geleid. Bij een wasrendement van $90 \%$ wordt hierdoor afgerond $75 \%$ van de totale ammoniakemissie gereduceerd.

\section{Toelichting praktische implementatie}

De maatregel is toepasbaar in alle bestaande vleeskuikenstallen die nog geen luchtzuivering bevatten ( $(E 5.6,5.10,5.11,5.14$ en 5.100). De maatregel kan in bestaande stallen met lengteventilatie worden ingepast. Verwacht wordt dat de maatregel vanaf 2020 effectief kan zijn en implementatie 5-6 jaar zal vergen.

\section{Toelichting kosten}

Investering voor een luchtwasser op $50 \%$ van max. ventilatieniveau vergt investering van $€ 2,10$ per dierplaats en jaarkosten van $€ 0,63$ per dierplaats. Er zijn 42 miljoen vleeskuikens in Nederland. Stel dat dit nog voor $100 \%$ van de dierplaatsen toegepast moet worden, dan is de investering $€ 2,10$ maal 42 miljoen kuikens is $€ 88$ miljoen en jaarkosten $€ 26,5$ miljoen tot 2030 . Tot en met 2025 is dan de helft hiervan. 


\subsection{Rundvee}

3.2.1 Factsheet 3a. Introductie mestschuiven in stallen met roostervloer zonder mestschuif

\begin{tabular}{|c|c|}
\hline \multicolumn{2}{|c|}{ 3a. Introductie mestschuiven in stallen met roostervloer zonder mestschuif } \\
\hline \multicolumn{2}{|c|}{$\begin{array}{l}\text { Door introductie van mestschuiven in stallen met een roostervloer die hiermee nog niet zijn } \\
\text { uitgerust wordt ammoniakemissie van stalvloeren verminderd omdat urine frequent (per } 2 \text { uur) en } \\
\text { effectiever wordt afgevoerd en minder als plassen op de roostervloer achterblijft. } \\
\text { Deze maatregel is toepasbaar in diercategorie A } 1.100 \text { en kan in bestaande stallen zonder } \\
\text { mestschuif worden ingebouwd. De ammoniakemissie-reductie wordt ingeschat op een bandbreedte } \\
\text { van } 5-10 \% \text {. }\end{array}$} \\
\hline Effectiviteit reductie & 2025 \\
\hline $\begin{array}{l}\text { Bij landelijke maatregelen: emissiedaling (kton } \\
\mathrm{N} / \mathrm{jr} \text { ) }\end{array}$ & 0,5 \\
\hline $\begin{array}{l}\text { Implementatie } \\
\text { (kosteneffectiviteit en tijdpad) }\end{array}$ & 2025 \\
\hline Kosteneffectiviteit (M€/kton $\mathrm{N}$ ) & 38,0 \\
\hline Investeringskosten voor de sector $(\mathrm{M} €)$ & 96 \\
\hline Operationele kosten voor de sector (M€/jr) & 19 \\
\hline Tijd benodigd voor invoering maatregel (jr) & Vanaf 2019 \\
\hline Termijn waarop effect wordt bereikt (jr) & $100 \%$ van de $\mathrm{A} 1.100$ stallen in 2025 \\
\hline \multicolumn{2}{|l|}{ Afdwingbaarheid en instrumentatie } \\
\hline $\begin{array}{l}\text { Verplicht in te voeren via wet- en regelgeving } \\
\text { (ja/nee) }\end{array}$ & $\begin{array}{l}\text { Ja, het is technisch mogelijk de aanwezigheid } \\
\text { van automatische mestschuif met een vast te } \\
\text { leggen minimaal prestatieniveau verplicht te } \\
\text { stellen. }\end{array}$ \\
\hline $\begin{array}{l}\text { Vrijwillig in te voeren via kennisdeling en } \\
\text { stimulering ( } \mathrm{ja} / \mathrm{nee})\end{array}$ & $\begin{array}{l}\text { Ja, door het verbeteren van de hygiëne op de } \\
\text { stalvoer mag verwacht worden dat deels } \\
\text { vrijwillige invoer plaatsvindt, stimulering van } \\
\text { deze maatregel zal implementatie verhogen. }\end{array}$ \\
\hline Vrijwillige afspraak (ja/nee) & $\begin{array}{l}\text { Ja, door het verbeteren van de hygiëne op de } \\
\text { stalvoer mag verwacht worden dat deels } \\
\text { vrijwillige invoer plaatsvindt. }\end{array}$ \\
\hline
\end{tabular}

\section{Toelichting maatregel}

Mestresten op stalvloeren belemmeren de afvoer van urine en leiden tot meer plasvorming en daardoor meer emissie. In de praktijk worden roostervloeren in veel gevallen nog met handmatig schuiven schoongehouden. De schoonmaakprestaties van de huidige aanpak in de praktijk kan verbeterd worden. Hierdoor wordt de hoeveelheid achterblijvende mestresten verminderd, en het volume van achterblijvende urineplassen en de omvang van hieruit emitterend ammoniak teruggedrongen.

De maatregel bestaat uit het installeren van doelmatige mestschuifsystemen waar deze nog niet aanwezig zijn (emissiereductie t.o.v. bestaande situatie 5-10\%)

Bovenstaande reductiepercentages van $10 \%$ op stalbasis is gebaseerd op modelberekening met het Snelstal emissiemodel (2019) waarin het effect van plasverwijdering met een schuiffrequentie van 12 maal per dag kan worden doorgerekend. De effectiviteit van volledige verwijdering van urine tijdens schuiven is echter niet met zekerheid vast te stellen, daarom wordt er ook met een geringer effect van 
$5 \%$ gerekend. De werkelijke effectiviteit zal in vergelijkend onderzoek proefondervindelijk vastgesteld moeten worden.

\section{Toelichting praktische implementatie}

De maatregel is toepasbaar in de Rav categorie A1.100, inschatting is dat de helft van de A1.100 bedrijven geen mestschuif heeft. Inschatting is dat deze maatregel stapsgewijs tussen 2019 en 2025 in alle A1.100 stallen kan zijn doorgevoerd.

\section{Toelichting kosten}

De investering voor mestschuiven begint bij $€ 113$ per dierplaats, maar afhankelijk van vloertype zijn er ook mestschuiven waarvoor de investering meer dan $€ 150$ bedraagt. Hier nemen we aan dat de investering voor een gemiddelde (standaard) mestschuif $€ 130$ per dierplaats bedraagt. Vanwege snelle afschrijving en hoge onderhoudskosten, worden de jaarkosten op $€ 26$ per koe geschat. Er zijn nog ca. $80 \%$ bedrijven met Rav categorie A1.100 en er zijn ca 1,6 miljoen melkkoeien in Nederland. Totale investering sector is dan de helft van $80 \% * 1,6$ miljoen maal $€ 150$ is $€ 96$ miljoen en jaarkosten $€ 19$ miljoen.

\subsubsection{Factsheet 3b. Spoelen vloer en verdunnen mest in stallen met roostervloer}

\section{3b. Spoelen/schuiven vloer en verdunnen mest in stallen met roostervloer}

Door introductie van spoelsystemen in stallen met roostervloer waarin met hoge frequentie (1 maal per half uur) de roostervloer wordt schoon gesproeid en geschoven (1 maal per 2 uur) wordt de ammoniakemissie van de stalvloeren en de onderliggende kelder verminderd. Het effect op de kelderemissie wordt daarbij bereikt door verdunning van de mest in de opslag. Deze maatregel is toepasbaar in diercategorie A1.100 en kan in bestaande stallen worden ingebouwd. De ammoniakemissie-reductie wordt ingeschat op 35\%.

\begin{tabular}{|c|c|}
\hline Effectiviteit reductie & 2025 \\
\hline $\begin{array}{l}\text { Bij landelijke maatregelen: emissiedaling (kton } \\
\mathrm{N} / \mathrm{jr} \text { ) }\end{array}$ & 3,5 \\
\hline $\begin{array}{l}\text { Implementatie } \\
\text { (kosteneffectiviteit en tijdpad) }\end{array}$ & 2025 \\
\hline Kosteneffectiviteit ( $€ /$ kton $N$ ) & 7,3 \\
\hline Investeringskosten voor de sector (M€) & 160 \\
\hline Operationele kosten voor de sector (M€/jr) & 25,6 \\
\hline Tijd benodigd voor invoering maatregel (jr) & Vanaf 2019 \\
\hline Termijn waarop effect wordt bereikt (jr) & $100 \%$ van de $A 1.100$ stallen in 2025 \\
\hline \multicolumn{2}{|l|}{ Afdwingbaarheid en instrumentatie } \\
\hline $\begin{array}{l}\text { Verplicht in te voeren via wet- en regelgeving } \\
\text { (ja/nee) }\end{array}$ & $\begin{array}{l}\text { Ja, het is technisch mogelijk de } \\
\text { aanwezigheid van spoelsysteem en } \\
\text { mestschuiven met een vast te leggen } \\
\text { minimaal prestatieniveau verplicht te } \\
\text { stellen. }\end{array}$ \\
\hline $\begin{array}{l}\text { Vrijwillig in te voeren via kennisdeling en } \\
\text { stimulering (ja/nee) }\end{array}$ & $\begin{array}{l}\text { Ja, door het verbeteren van de hygiëne op } \\
\text { de stalvoer mag verwacht worden dat } \\
\text { deels vrijwillige invoer plaatsvindt, } \\
\text { stimulering van deze maatregel zal } \\
\text { implementatie verhogen. }\end{array}$ \\
\hline Vrijwillige afspraak (ja/nee) & $\begin{array}{l}\text { Ja, door het verbeteren van de hygiëne op } \\
\text { de stalvoer mag verwacht worden dat } \\
\text { deels vrijwillige invoer plaatsvindt. }\end{array}$ \\
\hline
\end{tabular}




\section{Toelichting maatregel}

Mestresten op stalvloeren belemmeren de afvoer van urine en leiden tot meer plasvorming en daardoor meer emissie. In de praktijk worden roostervloeren in veel gevallen nog met handmatig schuiven schoongehouden. De afvoer van urine van de vloer kan door frequent spoelen met water over de roosters (elk half uur) en schuiven (elke 2 uur) verbeterd worden. Hierdoor wordt het voorkomen van achterblijvende urineplassen verminderd, en de omvang van hieruit emitterend ammoniak teruggedrongen. Door te werken met $10 \mathrm{liter} / \mathrm{m}^{2}$ spoelvloeistof (water) per dag wordt de opgeslagen mest in de kelder verdund waardoor de emissie hieruit door de lagere ammoniumconcentraties aan het oppervlak wordt verminderd.

De maatregel bestaat uit het installeren van een doelmatig sproei- en schuifsysteem. Een voorbeeld hoe deze uitgerust moet worden kan afgeleid worden van de huidige proefinstallatie die gebruikt wordt voor onderzoek op Dairy Campus in Leeuwarden (rapportage eind 2019).

Bovenstaand reductiepercentage van $35 \%$ op stalbasis is gebaseerd op de voorlopige proefresultaten die in een vergelijkende proefopzet op Dairy Campus zijn vastgesteld.

\section{Toelichting praktische implementatie}

De maatregel is toepasbaar in de Rav categorie A1.100. Inschatting is dat deze maatregel stapsgewijs tussen 2019 en 2025 in alle A1.100 stallen kan zijn doorgevoerd.

\section{Toelichting kosten}

Wordt nog aangepast op basis van gegevens fabrikant

Aangenomen wordt dat deze verbeterde mestschuiven wat duurder zijn dan de nu gebruikelijke mestschuiven en de investering $€ 80$ per melkkoe bedraagt. Vanwege snelle afschrijving en hoge onderhoudskosten, worden de jaarkosten op $€ 16$ per koe geschat. Er zijn 1,6 miljoen melkkoeien in Nederland. Totale investering sector is dan $€ 126$ miljoen en jaarkosten $€ 25,6$ miljoen. 


\subsubsection{Factsheet 4. Ventilatiemanagement gericht op beperkt debiet}

\section{Ventilatiemanagement gericht op beperkt debiet in melkveestallen}

De maatregel beoogt door het verkleinen van de luchtinlaat het ventilatiedebiet te verlagen en daarmee de luchtsnelheid over het emitterend oppervlak te reduceren. Dit kan worden gerealiseerd met regelbare gordijnen.

Volgens Mosquera et al. (2016) betekent een reductie van de ventilatie in melkveestallen met $25 \%$ een ammoniakemissiereductie van $10 \%$.

\begin{tabular}{|c|c|}
\hline Effectiviteit reductie & 2025 \\
\hline $\begin{array}{l}\text { Bij landelijke maatregelen: emissiedaling (kton } \\
\mathrm{N} / \mathrm{jr} \text { ) }\end{array}$ & 1,1 \\
\hline $\begin{array}{l}\text { Implementatie } \\
\text { (kosteneffectiviteit en tijdpad) }\end{array}$ & 2025 \\
\hline Kosteneffectiviteit ( $\mathrm{m} \ln € /$ kton $\mathrm{N}$ ) & 16,8 \\
\hline Investeringskosten voor de sector ( $\mathrm{mln} . €$ ) & 120 \\
\hline Operationele kosten voor de sector ( $\mathrm{mln} . € / \mathrm{jr}$ ) & 18 \\
\hline Tijd benodigd voor invoering maatregel (jr) & Vanaf 2020 \\
\hline Termijn waarop effect wordt bereikt (jr) & $100 \%$ in 2025 \\
\hline \multicolumn{2}{|l|}{ Afdwingbaarheid en instrumentatie } \\
\hline $\begin{array}{l}\text { Verplicht in te voeren via wet- en regelgeving } \\
(\mathrm{ja} / \mathrm{nee})\end{array}$ & $\begin{array}{l}\text { Ja, maar dan dient tbv handhaving online } \\
\text { regeling gelogd te worden. }\end{array}$ \\
\hline $\begin{array}{l}\text { Vrijwillig in te voeren via kennisdeling en } \\
\text { stimulering ( } \mathrm{ja} / \mathrm{nee})\end{array}$ & $\begin{array}{l}\text { Beperkt, gaat tegen trend van laatste jaren in } \\
\text { om stallen steeds meer open te maken. }\end{array}$ \\
\hline Vrijwillige afspraak (ja/nee) & Zie boven \\
\hline
\end{tabular}

\section{Toelichting maatregel}

De lange zijwanden van rundveestallen zijn vaak open en voorzien van gordijnen. Het ventilatiedebiet wordt verkleind door de ventilatieopening kleiner te maken door de gordijnen omhoog te doen (gordijnen sluiten in rundveestallen van onder naar boven). Door de grote variatie in emissie en ventilatie in de praktijk moet de ventilatie minstens $25 \%$ lager zijn dan zonder management van de inlaatopeningen om aantoonbaar ammoniakemissie te reduceren.

\section{Toelichting praktische implementatie}

De laatste jaren is de trend in de melkveehouderij erop gericht de koeien maximaal zichtbaar te maken door de stallen zo open mogelijk te bouwen. Dit past bij de maatschappelijke vraag naar transparantie. Deze maatregel gaat tegen deze trend in.

Om te handhaven wordt aanbevolen een regelsysteem te installeren die tevens de gordijnstanden kan registreren en vastleggen (loggen). De meeste stallen hebben gordijnen, de kosten behelzen dan een mechanische regeling en computergestuurde regelaar. Om weersafhankelijk te kunnen regelen is een weerstation nodig.

Omdat aangenomen wordt dat de boeren al gordijnen hebben kan er van uitgegaan worden dat implementatie op korte termijn mogelijk is en is de aanname dat $100 \%$ in 2025 , op technische gronden, geïmplementeerd kan zijn. Regelsystemen en weerstations zijn vrij algemeen verkrijgbaar en er wordt vanuit gegaan dat de levering van deze producten niet tijd beperkend zal zijn voor de implementatie. 


\section{Toelichting kosten}

Uitgaande van een stallengte van 0,5 m per koe, wordt het gordijnoppervlak 1,5 $\mathrm{m}^{2}$ per koe. De investering voor ventilatiesysteem met gordijnen met volautomatische regeling is ca. $€ 100$ per $\mathrm{m}^{2}$ (Bron: Groeien 2013, Investeringsgids voor melkveehouders), wat dus neer komt op $€ 150$ per melkkoe. De jaarkosten zijn dan ca. $€ 20$ per dierplaats. Er wordt aangenomen dat als implementatie afhangt van technische aspecten, 5 jaar nodig is voor volledig implementatie.

Wanneer al gordijnen aanwezig zijn zullen de kosten halveren, dus $€ 75$ per melkkoe met jaarkosten van $€ 11$.

Bij de kostenberekeningen is ervan uitgegaan dat de boeren al gordijnen hebben en dat implementatie dus op korte termijn kan. Er zijn circa 1,6 miljoen melkkoeien. Dus investering tot 2025 is $€ 120$ miljoen en jaarkosten $€ 18$ miljoen. We gaan ervan uit dat alle boeren al gordijnen hebben. Wanneer ook gordijnen geïnstalleerd moeten worden, verdubbelen de kosten.

\subsubsection{Factsheet 5. Luchtzuivering in de nok}

\section{Inpassing luchtzuivering in runderstallen via nok-ventilatie}

De maatregel voorziet in het plaatsen van mechanische ventilatie en een luchtwasser. Om het open karakter van de stal te handhaven hoeft niet alle lucht via de nok te worden afgevoerd en gereinigd.

Luchtzuivering via de nok kan het best ingepast worden in nieuwbouwstallen die bestaande conventionele huisvesting (A1.100) vervangen.

Wanneer het aandeel ongezuiverde lucht beperkt blijft tot 25\% kan de ammoniakemissie-reductie door deze maatregel $65 \%$ bedragen.

\begin{tabular}{|c|c|}
\hline Effectiviteit reductie & 2030 \\
\hline $\begin{array}{l}\text { Bij landelijke maatregelen: emissiedaling (kton } \\
\mathrm{N} / \mathrm{jr} \text { ) }\end{array}$ & 2,6 \\
\hline $\begin{array}{l}\text { Implementatie } \\
\text { (kosteneffectiviteit en tijdpad) }\end{array}$ & 2030 \\
\hline Kosteneffectiviteit (M€/kton N) & 35,8 \\
\hline Investeringskosten voor de sector (M€) & 304 \\
\hline Operationele kosten voor de sector (M€/jr) & 93 \\
\hline Tijd benodigd voor invoering maatregel (jr) & $\begin{array}{l}\text { Luchtzuivering via nok met automatische } \\
\text { inlaat-sturing: vanaf } 2021 \text {. }\end{array}$ \\
\hline Termijn waarop effect wordt bereikt (jr) & $20 \%$ in 2025 en $40 \%$ in 2030 \\
\hline \multicolumn{2}{|l|}{ Afdwingbaarheid en instrumentatie } \\
\hline $\begin{array}{l}\text { Verplicht in te voeren via wet- en regelgeving } \\
\text { (ja/nee) }\end{array}$ & Ja, is geschikt als te kiezen Rav-maatregel \\
\hline $\begin{array}{l}\text { Vrijwillig in te voeren via kennisdeling en } \\
\text { stimulering (ja/nee) }\end{array}$ & $\begin{array}{l}\text { Ja, stimulering kan het implementatieniveau } \\
\text { verhogen }\end{array}$ \\
\hline Vrijwillige afspraak (ja/nee) & Nee \\
\hline
\end{tabular}

\section{Toelichting maatregel}

De stallucht in melkveestallen wordt in de praktijk met een natuurlijk ventilatiesysteem ververst. De stallen zijn uitgerust met grote inlaatvlakken aan weerzijden van de stal en een open nok waardoor de lucht wordt afgevoerd. Deze stallen hebben hierdoor een open karakter. Natuurlijke ventilatie is niet geschikt voor toepassing van luchtzuiveringstechnieken. Om deze technieken te kunnen benutten 
is een mechanisch ventilatiesysteem nodig. Dergelijke ventilatiesystemen kunnen echter het open karakter van stallen verstoren. Om enerzijds het hoge verwijderingsrendement van luchtwassers te kunnen benutten en anderzijds het gewenste open karakter van melkveestallen dient de uitvoering en regeling van het ventilatiesysteem op deze eisen te worden aangepast.

De maatregel bestaat uit:

- Het aanbrengen van een mechanisch ventilatiesysteem met grote regelbare inlaatopeningen aan weerszijden van de stal, die het open karakter van de stal intact laat. In de nok van de stal worden ventilatoren opgenomen die de stallucht afvoeren naar een luchtwasser.

- De regelbare inlaatopeningen aan weerzijden van de stal worden afzonderlijk automatisch aangestuurd, waarbij afhankelijk van windrichting en snelheid één zijde zoveel mogelijk open blijft en de ander zoveel als nodig gesloten. Op deze wijze wordt dwarsventilatie van ongezuiverde stallucht beperkt tot ca. $25 \%$ van het totale ventilatievolume.

Aangestuurde inlaatopeningen leiden tot een behandelbare luchtstroom die $75 \%$ van het totale ventilatievolume bedraagt. Uitgaande van het verwijderingsrendement van een chemische wasser van $90 \%$, bedraagt de reductie van de stalemissie $75 \times 0.90=$ afgerond $65 \%$.

\section{Toelichting praktische implementatie}

Implementatie vanuit technisch oogpunt, uitgaande van de verplichting van de maatregel voor alle stallen met Rav-code A1.100 zal kunnen starten vanaf 2021, afhankelijk van de beschikbaarheid van op rundveestallen toegeruste luchtwassers en ventilatieregelingen.

Deze maatregel kan het best ingepast worden in nieuwbouwstallen die bestaande conventionele huisvesting (A1.100) vervangen. Implementatie in de praktijk hangt daarmee af van het vervangingsritme van stallen. Voor nieuwbouw van rundveestallen wordt overigens de kanttekening geplaatst dat door uitgestelde investeringen in de rundveestallen het afgelopen decennium en de afschaffing van het melkquotum, de laatste paar jaar heel veel nieuwbouw heeft plaatsgevonden. Het bestand aan stallen is echter dermate oud, dat we de gemiddelde investeringssnelheid van $4 \%$ voor nieuwe stallen handhaven. Bij volledige implementatie zal het effect op de emissie 6,5 kton $\mathrm{NH}_{3}-\mathrm{N}$ bedragen, bij een fasering van 4\% per jaar zal de reductie tot 2025 en 2030 respectievelijk $20 \%$ en $40 \%$ van deze waarde zijn.

\section{Toelichting kosten}

De investering bedraagt $€ 475$ per melkkoe. De jaarkosten voor rente, afschrijving en onderhoud bedragen $€ 63$ per koe en de exploitatiekosten (hoofdzakelijk energie) bedragen $€ 82$ per koe. Totale jaarkosten dus $€ 145$ per melkkoe. Er zijn 1,6 miljoen melkkoeien in Nederland. Als $4 \%$ per jaar een nieuwe stal bouwt, dan is de jaarlijkse investering 4\%*1,6 miljoen * $€ 475=€ 30,4$ miljoen. Tot 2025 een investering van $5 * 30,4=€ 152$ miljoen. Jaarkosten zijn $4 \% * 1,6$ miljoen $* € 145=€ 9,3$ miljoen. In 2025 (dus voor de jaren 2021 tot 2025) jaarkosten van $5 * 9,3=€ 46,5$ miljoen. In 2030 is dat respectievelijk $10 * 30,4=€ 304$ miljoen en $10 * 9,3=€ 93$ miljoen. 


\begin{tabular}{|c|c|}
\hline \multicolumn{2}{|c|}{ 6. Inpassing luchtzuivering in runderstallen via kelder-ventilatie } \\
\hline Effectiviteit reductie & 2030 \\
\hline $\begin{array}{l}\text { Bij landelijke maatregelen: emissiedaling (kton } \\
\mathrm{N} / \mathrm{jr} \text { ) }\end{array}$ & 1,0 \\
\hline $\begin{array}{l}\text { Implementatie } \\
\text { (kosteneffectiviteit en tijdpad) }\end{array}$ & 2030 \\
\hline Kosteneffectiviteit (M€/kton $\mathrm{N}$ ) & 45,0 \\
\hline Investeringskosten voor de sector $(\mathrm{M} €)$ & 180 \\
\hline Operationele kosten voor de sector (M€/jr) & 45,0 \\
\hline Tijd benodigd voor invoering maatregel (jr) & $\begin{array}{l}\text { Luchtzuivering via kelder met automatische } \\
\text { inlaat-sturing: vanaf } 2021 \text {. }\end{array}$ \\
\hline Termijn waarop effect wordt bereikt (jr) & $2021-2030$ \\
\hline \multicolumn{2}{|l|}{ Afdwingbaarheid en instrumentatie } \\
\hline $\begin{array}{l}\text { Verplicht in te voeren via wet- en regelgeving } \\
\text { (ja/nee) }\end{array}$ & Ja, is geschikt als te kiezen Rav-maatregel \\
\hline $\begin{array}{l}\text { Vrijwillig in te voeren via kennisdeling en } \\
\text { stimulering ( } \mathrm{ja} / \mathrm{nee})\end{array}$ & $\begin{array}{l}\text { Ja, stimulering kan het implementatieniveau } \\
\text { verhogen }\end{array}$ \\
\hline Vrijwillige afspraak (ja/nee) & Nee \\
\hline
\end{tabular}

\section{Toelichting maatregel}

De stallucht in melkveestallen wordt in de praktijk met een natuurlijk ventilatiesysteem ververst. Natuurlijke ventilatie is niet geschikt voor toepassing van luchtzuiveringstechnieken. Om deze technieken te kunnen benutten is een mechanisch ventilatiesysteem nodig. Om enerzijds het hoge verwijderingsrendement van luchtwassers te kunnen benutten en anderzijds het gewenste open karakter van melkveestallen, dient de uitvoering en regeling van het ventilatiesysteem op deze eisen te worden aangepast. Dit kan bereikt worden door een combinatie van natuurlijke en mechanische ventilatie toe te passen. Zo is het mogelijk de lucht in de kelderopslag onder de roosters afzonderlijk mechanisch af te voeren en te zuiveren, terwijl de stal natuurlijk geventileerd blijft.

De maatregel bestaat uit:

- Het aanbrengen van een afzuigsysteem onder de roosters om de lucht in de mestkelders separaat af te voeren en te behandelen. De stallucht boven de roosters wordt via natuurlijke ventilatie ververst. Door het afzuigsysteem wordt uitwisseling van kelderlucht met de stal tegengegaan.

- Het plaatsen van een luchtwasser die de mechanische geventileerde kelderlucht zuivert. Hierdoor wordt het merendeel van het aandeel van de kelderemissie in de totale stalemissie teruggedrongen. Gerekend over de volledige stalemissie bedraagt de reductie $25 \%$.

Bij het berekenen van het reductiepercentage bij stallen met roostervloeren (A1.100) is er van uitgegaan dat de verhouding 'vloeremissie : kelderemissie' 60:40 is. Tevens is de aanname dat effectief $80 \%$ van de kelderlucht wordt afgezogen. Deze wordt gezuiverd met een chemische luchtwasser met een verwijderings-rendement van 90\%. Dit leidt tot een netto emissiereductie op stal basis van $40 \times 0.75 \times 0.90=$ afgerond $25 \%$ op stalbasis. 


\section{Toelichting praktische implementatie}

Implementatie vanuit technisch oogpunt, uitgaande van de verplichting van de maatregel voor alle stallen met Rav-code A1.100 zal kunnen starten vanaf 2021, afhankelijk van de beschikbaarheid van op rundveestallen toegeruste luchtwassers en ventilatieregelingen.

Deze maatregel kan het best ingepast worden in nieuwbouwstallen die bestaande conventionele huisvesting (A1.100) vervangen. Implementatie in de praktijk hangt daarmee af van het vervangingsritme van stallen. Voor nieuwbouw van rundveestallen wordt overigens de kanttekening geplaatst dat door uitgestelde investeringen in de rundveestallen het afgelopen decennium en de afschaffing van het melkquotum, de laatste paar jaar heel veel nieuwbouw heeft plaatsgevonden. Het bestand aan stallen is echter dermate oud, dat we de gemiddelde investeringssnelheid van $4 \%$ voor nieuwe stallen handhaven. Bij volledige implementatie zal het effect op de emissie 2,5 kton $\mathrm{NH}_{3}-\mathrm{N}$ bedragen, bij een fasering van 4\% per jaar zal de reductie tot 2025 en 2030 respectievelijk $20 \%$ en $40 \%$ van deze waarde zijn.

\section{Toelichting kosten}

De investering bedraagt $€ 280$ per melkkoe. De jaarkosten voor rente, afschrijving en onderhoud bedragen $€ 36$ per koe en de exploitatiekosten (hoofdzakelijk energie) bedragen $€ 34$ per koe. Totale jaarkosten dus $€ 70$ per melkkoe. Er zijn 1,6 miljoen melkkoeien in Nederland. Als $4 \%$ per jaar een nieuwe stal bouwt, dan is de jaarlijkse investering 4\%*1,6 miljoen * $€ 280=€ 18$ miljoen. Tot 2025 een investering van $5 * 18=€ 90$ miljoen. Jaarkosten zijn $4 \% * 1,6$ miljoen $* € 70=€ 4,5$ miljoen. Tot 2025 jaarkosten van $5 * 4,5=€ 22,5$ miljoen.

Tot 2030 is dat respectievelijk $10 * 18=€ 180$ miljoen en $10 * 4,5=€ 45$ miljoen.

\subsubsection{Factsheet 7. Mest koelen}

\section{Het koelen van onder de roostervloer opgeslagen mest.}

Door de mest onder de roostervloer te koelen met ca. 4 graden kan de emissie uit de mestkelder worden verminderd met $15 \%$.

\begin{tabular}{|c|c|}
\hline Effectiviteit reductie & 2030 \\
\hline $\begin{array}{l}\text { Bij landelijke maatregelen: emissiedaling (kton } \\
\mathrm{N} / \mathrm{jr} \text { ) }\end{array}$ & 1,5 \\
\hline $\begin{array}{l}\text { Implementatie } \\
\text { (kosteneffectiviteit en tijdpad) }\end{array}$ & 2030 \\
\hline Kosteneffectiviteit (M€/kton $\mathrm{N}$ ) & 32 \\
\hline Investeringskosten voor de sector (M€) & $480 *$ \\
\hline Operationele kosten voor de sector $(\mathrm{M} € / \mathrm{jr}$ ) & 48 \\
\hline Tijd benodigd voor invoering maatregel (jr) & 10 jaar \\
\hline \multicolumn{2}{|l|}{ Termijn waarop effect wordt bereikt (jr) } \\
\hline \multicolumn{2}{|l|}{ Afdwingbaarheid en instrumentatie } \\
\hline $\begin{array}{l}\text { Verplicht in te voeren via wet- en regelgeving } \\
\text { (ja/nee) }\end{array}$ & $\begin{array}{l}\text { Ja, is geschikt als uit te werken Rav- } \\
\text { maatregel }\end{array}$ \\
\hline $\begin{array}{l}\text { Vrijwillig in te voeren via kennisdeling en } \\
\text { stimulering (ja/nee) }\end{array}$ & $\begin{array}{l}\text { Ja, stimulering kan het implementatieniveau } \\
\text { verhogen. Het reducerende effect op } \\
\text { methaan zal tevens stimulerend werken }\end{array}$ \\
\hline Vrijwillige afspraak (ja/nee) & Nee \\
\hline
\end{tabular}

* Mogelijk zijn kosten terug te verdienen door de warmte terug te winnen en daarmee melkveebedrijven gasloos te maken. Daarvoor is wel een extra investering nodig in een warmtepomp en buffervat, ca $€ 200$ per koe. 


\section{Toelichting maatregel}

Het koelen werkt emissiereducerend doordat het transport van ammoniak naar de luchtlaag boven de mest wordt afgeremd. Bij stallen met roostervloer komt ongeveer $40 \%$ van de stalemissie uit de kelder. In eerder onderzoek van Groenestein en Huis in 't Veld (1996) bij koelen van varkensmest bleek dat de emissie uit de kelder met $40 \%$ kon worden teruggedrongen. Wanneer dit percentage wordt toegepast op de $40 \%$ kelderemissie uit melkveestallen, wordt een emissiereductie over de gehele stalemissie van afgerond $15 \%$ bereikt.

\section{Toelichting praktische implementatie}

Koelen van mest in rundveestallen kan niet met koel-lamellen die de toplaag koelen plaatsvinden omdat deze systemen bij rundveemest op de toplaag gaan drijven. Er moet daarom bulk-koeling van de gehele mest worden nagestreefd. Momenteel zijn een aantal bedrijven in Nederland met een dergelijke koelinstallatie uitgerust. Deze systemen zijn ontworpen om de methaanemissie terug te dringen maar kunnen tevens een positief effect op de ammoniakemissie bewerkstelligen.

\section{Toelichting kosten}

De investering voor een koelinstallatie vergt een investering van ca. $€ 30.000$ per bedrijf, $€ 300$ per koe. De jaarlijkse kosten zullen $€ 30$ per koe bedragen. Waarschijnlijk is het goed mogelijk deze kosten terug te verdienen door de warmte terug te winnen en daarmee melkveebedrijven gasloos te maken. Daarvoor is wel een extra investering nodig in een warmtepomp en buffervat, ca $€ 200$ per koe.

\subsubsection{Factsheet 8a. Frequent mest verwijderen uit de stal zonder mestopslag} onder de vloer in nieuwe stallen

\section{Frequent mest verwijderen uit de stal zonder mestopslag onder de vloer in nieuwe stallen}

In melkveestallen met roostervloer kan de ammoniakemissie worden teruggedrongen met 55\% door de onderliggende mestopslag volledig af te sluiten door een dichte vloer en de mest met hoge frequentie (elk uur) af te voeren naar een externe mestopslag. Naast een afname van de ammoniakemissie neemt door de directe verwijdering van mest en het ontbreken van mestopslag onder de vloer ook de methaanemissie uit de stal af.

\begin{tabular}{|c|c|}
\hline Effectiviteit reductie & 2030 \\
\hline $\begin{array}{l}\text { Bij landelijke maatregelen: emissiedaling (kton } \\
\mathrm{N} / \mathrm{jr} \text { ) }\end{array}$ & 2,75 \\
\hline $\begin{array}{l}\text { Implementatie } \\
\text { (kosteneffectiviteit en tijdpad) }\end{array}$ & 2030 \\
\hline Kosteneffectiviteit (M€/kton $\mathrm{N}$ ) & 7,0 \\
\hline Investeringskosten voor de sector $(\mathrm{M} \epsilon)$ & 192 \\
\hline Operationele kosten voor de sector (M€/jr) & 19,2 \\
\hline Tijd benodigd voor invoering maatregel (jr) & Vanaf $2020100 \%$ in 25 jaar \\
\hline Termijn waarop effect wordt bereikt (jr) & $40 \%$ in 2030 \\
\hline \multicolumn{2}{|l|}{ Afdwingbaarheid en instrumentatie } \\
\hline $\begin{array}{l}\text { Verplicht in te voeren via wet- en regelgeving } \\
\text { (ja/nee) }\end{array}$ & $\begin{array}{l}\text { Ja, is geschikt als uit te werken Rav- } \\
\text { maatregel }\end{array}$ \\
\hline $\begin{array}{l}\text { Vrijwillig in te voeren via kennisdeling en } \\
\text { stimulering (ja/nee) }\end{array}$ & $\begin{array}{l}\text { Ja, stimulering kan het implementatieniveau } \\
\text { verhogen. Het reducerende effect op } \\
\text { methaan zal tevens stimulerend werken }\end{array}$ \\
\hline Vrijwillige afspraak (ja/nee) & Nee \\
\hline
\end{tabular}




\section{Toelichting maatregel}

Door de geproduceerde mest extern i.p.v. in de stal op te slaan vindt er geen opslag-emissie meer plaats uit de stal (NB wel is er dan nog sprake van enige extra ammoniakemissie uit de gesloten externe opslag). Op basis van modelberekening met het Snelstalmodel blijkt dat met elk uur mest verwijderen de vloeremissie met $25 \%$ kan worden teruggebracht t.o.v. het niet verwijderen van de mest. De kelderemissie wordt door het ontbreken van mest volledig geëlimineerd. Ten opzichte van een conventionele roostervloerstal met $60 \%$ vloeremissie en $40 \%$ kelderemissie resteert er bij deze aanpassing nog een emissie van $(60 \times 0.75)+(40 \times 0)=45 \%$, d.w.z. een reductie van $55 \%$. Naast een afname van de ammoniakemissie neemt door de directe verwijdering van mest en het ontbreken van mestopslag onder de vloer ook de methaanemissie uit de stal af. De ammoniakemissie uit de externe mestopslag is sterk gereduceerd (90\%) door verplichte afdekking. Om de methaanemissie tegen te gaan zijn extra maatregelen nodig.

\section{Toelichting praktische implementatie}

De geproduceerde mest en urine dient met hoge frequentie (elk uur) van de vloer te worden verwijderd met een mestschuifsysteem om de emissie van de vloer terug te dringen. De uitgeschoven mest moet vervolgens met een gesloten transportsysteem (bv. vijzel) in de externe mestopslag worden gebracht.

\section{Toelichting kosten}

De besparing op de investering bij kelderloos bouwen is ca. $€ 50$ per $\mathrm{m}^{2}$. Daarvoor in de plaats is een bovengrondse opslag nodig. Voor een bedrijf met 100 melkkoeien is een opslag nodig van $2.000 \mathrm{~m}^{3}$. De investering hiervoor bedraagt ca. $€ 40$ per $\mathrm{m} 3$, dus totaal $€ 80.000, € 800$ per koe. Minus een besparing van $€ 500$ ( 50 per $\mathrm{m} 2$ ) per koe, is de netto-investering $€ 300$ per koe. De jaarkosten hiervan zijn globaal $€ 30$ per koe. Bij 1,6 miljoen melkkoeien in Nederland gaat het om een investering van $€ 480$ miljoen en jaarlijkse kosten van $€ 48$ miljoen.

Deze maatregel kan alleen bij nieuwbouw uitgevoerd worden. Als jaarlijks $4 \%$ van de stallen vervangen wordt, dan kan deze maatregel in 2025 op $20 \%$ van de bedrijven geïmplementeerd zijn en in 2030 op $40 \%$ van de bedrijven. 


\begin{tabular}{|c|c|}
\hline \multicolumn{2}{|c|}{$\begin{array}{l}\text { 8b. Frequent mest verwijderen uit de stal zonder mestopslag onder de vloer in } \\
\text { bestaande stallen }\end{array}$} \\
\hline \multicolumn{2}{|c|}{$\begin{array}{l}\text { In melkveestallen met roostervloer kan de ammoniakemissie worden teruggedrongen met } 55 \% \\
\text { door de onderliggende mestopslag volledig af te sluiten door een dichte vloer en de mest met hoge } \\
\text { frequentie (elk uur) af te voeren naar een externe mestopslag. Naast een afname van de } \\
\text { ammoniakemissie neemt door de directe verwijdering van mest en het ontbreken van mestopslag } \\
\text { onder de vloer ook de methaanemissie uit de stal af. }\end{array}$} \\
\hline Effectiviteit reductie & 2030 \\
\hline $\begin{array}{l}\text { Bij landelijke maatregelen: emissiedaling (kton } \\
\mathrm{N} / \mathrm{jr} \text { ) }\end{array}$ & 5,5 \\
\hline $\begin{array}{l}\text { Implementatie } \\
\text { (kosteneffectiviteit en tijdpad) }\end{array}$ & 2030 \\
\hline Kosteneffectiviteit (M€/kton $\mathrm{N}$ ) & 20,9 \\
\hline Investeringskosten voor de sector (M€) & 1152 \\
\hline Operationele kosten voor de sector (M€/jr) & $115,2^{*}$ \\
\hline Tijd benodigd voor invoering maatregel (jr) & Vanaf 2020 \\
\hline Termijn waarop effect wordt bereikt (jr) & Voor alle huidige $\mathrm{A} 1.100$ stallen \\
\hline \multicolumn{2}{|l|}{ Afdwingbaarheid en instrumentatie } \\
\hline $\begin{array}{l}\text { Verplicht in te voeren via wet- en regelgeving } \\
\text { (ja/nee) }\end{array}$ & $\begin{array}{l}\text { Ja, is geschikt als uit te werken Rav- } \\
\text { maatregel }\end{array}$ \\
\hline $\begin{array}{l}\text { Vrijwillig in te voeren via kennisdeling en } \\
\text { stimulering (ja/nee) }\end{array}$ & $\begin{array}{l}\text { Ja, stimulering kan het implementatieniveau } \\
\text { verhogen. Het reducerende effect op } \\
\text { methaan zal tevens stimulerend werken }\end{array}$ \\
\hline Vrijwillige afspraak (ja/nee) & Nee \\
\hline
\end{tabular}

* uitgangspunt is dat nieuw te bouwen buitenopslag vereist is omdat bestaande niet voldoende is.

\section{Toelichting maatregel}

Door de geproduceerde mest extern i.p.v. in de stal op te slaan vindt er geen opslag-emissie meer plaats uit de stal (NB wel is er dan nog sprake van enige extra ammoniakemissie uit de gesloten externe opslag). Op basis van modelberekening met het Snelstalmodel blijkt dat met elk uur mest verwijderen de vloeremissie met $25 \%$ kan worden teruggebracht t.o.v. het niet verwijderen van de mest. De kelderemissie wordt door het ontbreken van mest volledig geëlimineerd. Ten opzichte van een conventionele roostervloerstal met $60 \%$ vloeremissie en $40 \%$ kelderemissie resteert er bij deze aanpassing nog een emissie van $(60 \times 0.75)+(40 \times 0)=45 \%$, d.w.z. een reductie van $55 \%$. Naast een afname van de ammoniakemissie neemt door de directe verwijdering van mest en het ontbreken van mestopslag onder de vloer ook de methaanemissie uit de stal af. De ammoniakemissie uit de externe mestopslag is sterk gereduceerd (90\%) door verplichte afdekking. Om de methaanemissie tegen te gaan zijn extra maatregelen nodig.

\section{Toelichting praktische implementatie}

De geproduceerde mest en urine dient met hoge frequentie (elk uur) van de vloer te worden verwijderd met een mestschuifsysteem om de emissie van de vloer terug te dringen. De uitgeschoven mest moet vervolgens met een gesloten transportsysteem (bv. vijzel) in de externe mestopslag worden gebracht. Het toepassen van deze maatregel door aanpassing van bestaande stallen leidt tot een snellere implementatie voor de A1.100 stallen. 


\section{Toelichting kosten}

Voor een bedrijf met 100 melkkoeien is een opslag nodig van $2.000 \mathrm{~m}^{3}$. De investering hiervoor bedraagt ca. $€ 40$ per $\mathrm{m} 3$, dus totaal $€ 80.000, € 800$ per koe. We gaan er in deze benadering van uit dat extra opslag gebouwd dient te worden omdat bestaande opslag niet voldoende is. Bij bestaande bedrijven is geen sprake van een besparing door kelderloos bouwen (zie factsheet 8a), maar juist een extra investering om de kelder af te sluiten. Samen met de investering voor de bovengrondse opslag, bedraagt de investering $€ 900$ per koe. De jaarkosten hiervan zijn over 10 jaar $€ 90$ per koe. Bij 1,6 miljoen melkkoeien in Nederland, waarvan $80 \%$ in A1.100 gehuisvest is gaat het om een investering van $€ 1152$ miljoen en jaarlijkse kosten van $€ 115,2$ miljoen. 


\title{
$4 \quad$ Voermaatregelen
}

\subsection{Rundvee}

\subsubsection{Factsheet 9. TAN-excretie melkvee verminderen via voerspoor}

\begin{abstract}
9. TAN-excretie verminderen op het melkveebedrijf met voermaatregelen De maatregel voorziet in een samenhangend geheel van voermaatregelen om de TAN-excretie te verminderen. Dit is voor alle melkveebedrijven in Nederland mogelijk, omdat het voerspoor veel mogelijkheden biedt. Vrijwel ieder Nederlands melkveebedrijf kan in het pakket van maatregelen in het voerspoor passende maatregelen vinden. De haalbare reductie ten opzichte van 2014 is voor een individueel bedrijf afhankelijk van de mate waarin het bedrijf het voerspoor al heeft benut.
\end{abstract}

\begin{tabular}{|c|c|}
\hline Effectiviteit reductie & 2030 \\
\hline $\begin{array}{l}\text { Bij landelijke maatregelen: emissiedaling (kton } \\
\mathrm{N} / \mathrm{jr} \text { ) }\end{array}$ & 4,4 \\
\hline $\begin{array}{l}\text { Implementatie } \\
\text { (kosteneffectiviteit en tijdpad) }\end{array}$ & 2030 \\
\hline Kosteneffectiviteit (M€/kton $\mathrm{N}$ ) & Levert op \\
\hline Investeringskosten voor de sector $(€)$ & - \\
\hline Operationele kosten voor de sector (M€/jr) & * \\
\hline Tijd benodigd voor invoering maatregel (jr) & $\begin{array}{l}\text { De maatregel kan direct worden } \\
\text { toegepast, maar vraagt een leertraject } \\
\text { van de melkveehouder voordat volledige } \\
\text { benutting van de potentie wordt bereikt. }\end{array}$ \\
\hline Termijn waarop effect wordt bereikt (jr) & $\begin{array}{l}\text { Direct effect bij implementatie, maar } \\
\text { geleidelijk toenemend afhankelijk van } \\
\text { leerproces veehouder }\end{array}$ \\
\hline \multicolumn{2}{|l|}{ Afdwingbaarheid en instrumentatie } \\
\hline Verplicht in te voeren via wet- en regelgeving (ja/nee) & $\mathrm{Ja}$ \\
\hline $\begin{array}{l}\text { Vrijwillig in te voeren via kennisdeling en stimulering } \\
\text { (ja/nee) }\end{array}$ & $\begin{array}{l}\text { Twijfelachtig. } \\
\text { Ja, omdat de maatregel in principe geld } \\
\text { oplevert. } \\
\text { Nee, omdat met managen van andere } \\
\text { verplichtingen meer is te } \\
\text { verdienen/besparen en dus daar de } \\
\text { aandacht en energie naar toe gaat. }\end{array}$ \\
\hline Vrijwillige afspraak (ja/nee) & $\begin{array}{l}\text { Afhankelijk hoeveel van het } \\
\text { reductiepotentieel gehaald moet worden } \\
\text { m.a.w. afhankelijk van hoever een } \\
\text { veehouder het leerproces wil doorlopen } \\
\text { (zonder andere incentive dan kosten } \\
\text { besparen via efficiënte voeding) }\end{array}$ \\
\hline
\end{tabular}

* Verhoging van melkproductie bij verbeterde voerefficiëntie en verlaging Re-gehalte voer is een continu optimaliseringsproces binnen de veehouderij en derhalve niet volledig toe te schrijven aan de maatregel. Derhalve is kwalitatief gewaardeerd. Zie toelichting kosten. 


\section{Toelichting maatregel}

In Bijlage 3 wordt toegelicht op welke wijze de verwachte emissiereductie als gevolg van het verlagen van de TAN-excretie op het melkveebedrijf is ingeschat. Bij de uitwerking van deze maatregel is aangenomen dat het reductie-effect voornamelijk via het melkveedeel van de melkveestapel moet worden bereikt. In principe zou je ook de TAN-excretie van jongvee kunnen verlagen door kwalitatief beter te voeren. Gedacht wordt dat dit in de praktijk wel mogelijk is, maar lastig uitvoerbaar. In de praktijk wordt $\mathrm{nl}$ het voer wat bij de melkkoeien over is voor het jongvee geschoven, waardoor van rantsoenoptimalisatie voor jongvee geen sprake is. Bovendien is niet al het ruwvoer dat op een bedrijf aanwezig is geschikt om op te nemen in scherp gevoerd melkvee (afhankelijk van oogstmoment, voorjaar/najaar en van het weer tijdens de groei en/of tijdens inkuilen). Jongvee krijgt in de regel het voor melkvee ongeschikte voer. De getallen in Bijlage 3 zijn voor het melkveebedrijf als geheel aan de hoge kant, omdat het jongvee daarin niet is meegenomen. Volgens de forfaits voor ammoniakemissie is het jongveedeel op een gemiddeld NL melkveebedrijf ca $20 \%$ van de ammoniakemissie. Onder aanname dat de ammoniakemissie van jongvee niet zal dalen betekent dat dat de reductie van de veestapelemissie op het melkveebedrijf ca. $80 \%$ van de reductie van de melkveestapel zal zijn (voor $\mathrm{NL}$ is dat voor 2020 en 2030 respectievelijk ca. 3,5\% en ca. 12,5\%).

\section{Toelichting praktische implementatie}

Het verlagen van de TAN-excretie door de veestapel is niet alleen effectief in het reduceren van de ammoniakemissie, maar gaat ook gepaard met een verbetering van de voerefficiëntie en leidt daarmee in principe tot verlaging van de (voer)kosten. De reden dat deze reductiepotentie nog niet volledig wordt benut is enerzijds ontbrekende kennis en kunde bij de veehouder en anderzijds de noodzaak en druk op de veehouder om zich met andere zaken bezig te houden. Bij de inschatting van de reductiepotentie en praktische implementatie is er van uitgegaan dat in 2030 zowel de kennis en kunde van de veehouder op peil zijn, als voldoende druk om de ammoniakemissie van het bedrijf te verminderen. Verder is aangenomen dat die ontwikkeling zich van nu tot 2030 geleidelijk voltrekt. Toepassen van deze doelmaatregel gebeurt via het voer- en diermanagement en is daarmee een pakket van maatregelen. Vrijwel ieder Nederlands melkveebedrijf kan in dat pakket passende maatregelen vinden. Het gaat daarbij niet om de toepassing van afzonderlijke voermaatregelen, maar om de combinatie van maatregelen.

\section{Toelichting kosten}

Verhoging van melkproductie bij verbeterde voerefficiëntie en verlaging Re-gehalte voer, levert verbetering van arbeidsinkomen op. Tot 2020 is dit ca $€ 60$ per melkkoe; voor 1,6 mln melkkoeien dus $€-96 \mathrm{mln}$. In 2030 is dit opgelopen tot $€ 200$ per melkkoe. Echter, efficiëntieverbetering is een doorlopende autonome ontwikkeling. En derhalve niet enkel toe te schrijven aan de ammoniakemissiereductie-maatregel. Er kan wel gesteld worden dat de maatregel geld oplevert. Dit is daarom kwalitatief opgenomen in de tabel. 


\section{$5 \quad$ Toediening}

\subsection{Algemeen}

Er zijn geen nieuwe technieken voorhanden om de mest emissiearm toe te dienen. De maatregelen voorzien in het combineren van bestaande technieken en maatregelen en een methode uit het verleden. Benoemde potentiële emissiereducties zijn eerste inschattingen die nog verder onderbouwd dienen te worden.

\subsubsection{Factsheet 10. Verbeteren van effectiviteit van toedieningstechnieken}

\section{Verbetering effectiviteit en borging huidige toedieningstechnieken}

Effectiviteit van huidige technieken verbeteren; nauwkeurigheid van werken op grasland en bouwland; differentiatie naar grondsoort. Is het werkresultaat na de mesttoediening overeenkomend met dat van een zodenbemester of sleepvoet/sleufkouter ? Nauwkeurig werken heeft alles te maken met mestgift, verdeelnauwkeurigheid van de mest over werkbreedte machine, bodemcondities en afstellingsmogelijkheden van de machine. De chauffeur speelt hierbij ook een belangrijke rol.

Effectiviteit van uitvoering bestaande maatregelen kan daarbij verbeteren door verbeterde borging. Borging kan een aspect zijn van eisen van de NVWA. In principe kan ook geborgd worden op de machine door registratie en sturing afstelling machine, opdat de mesttoediening netjes gebeurd en/of door gecertificeerde uitvoerders van de bemesting (opleiding).

Uitgegaan wordt van een emissiereductie van $25 \%$ bij zodenbemesting (ten opzichte van huidige emissiefactor van 19\%). In de berekeningen is uitgegaan van een emissiefactor van $14 \%$ voor zodenbemesting

(Mogelijk straks nog wel onderscheid naar grondsoorten)

\begin{tabular}{|c|c|}
\hline Effectiviteit reductie & 2030 \\
\hline Bij landelijke maatregel: emissiedaling (kton $\mathrm{N} / \mathrm{jr}$ ) & 6,1 \\
\hline $\begin{array}{l}\text { Implementatie } \\
\text { (kosteneffectiviteit en tijdpad) }\end{array}$ & 2030 \\
\hline Kosteneffectiviteit (M€/kton $\mathrm{N}$ ) & 4,9 \\
\hline Investeringskosten voor de sector $(\mathrm{M} \epsilon)$ & - \\
\hline Operationele kosten voor de sector (M€/jr) & 30 \\
\hline Tijd benodigd voor invoering maatregel (jr) & 5-10 jaar \\
\hline Termijn waarop effect wordt bereikt (jr) & 5-10 jaar \\
\hline \multicolumn{2}{|l|}{ Afdwingbaarheid en instrumentatie } \\
\hline $\begin{array}{l}\text { Verplicht in te voeren via wet- en regelgeving } \\
\text { (ja/nee) }\end{array}$ & $\begin{array}{l}\text { Het betreft "netter" werken gepaard gaande } \\
\text { met betere borging. De borging is veelal een } \\
\text { overheidsaangelegenheid. Veel zal afhangen } \\
\text { van noodzaak; verschillend voor individuele } \\
\text { bedrijven. Het betreft met name een } \\
\text { investering van loonwerker die evt. machine } \\
\text { moet aanpassen of meer tijd en aandacht zal } \\
\text { moeten besteden aan de werkzaamheden. De }\end{array}$ \\
\hline
\end{tabular}




\begin{tabular}{|c|c|}
\hline & $\begin{array}{l}\text { loonwerker zal de meerkosten willen } \\
\text { doorbelasten. }\end{array}$ \\
\hline $\begin{array}{l}\text { Vrijwillig in te voeren via kennisdeling en } \\
\text { stimulering ( } \mathrm{ja} / \mathrm{nee})\end{array}$ & $\begin{array}{l}\text { Het "netter" werken kan gestimuleerd } \\
\text { worden. Veel zal afhangen van noodzaak; } \\
\text { verschillend voor individuele bedrijven. Het } \\
\text { betreft met name een investering van } \\
\text { loonwerker die evt. machine moet aanpassen } \\
\text { of meer tijd en aandacht zal moeten besteden } \\
\text { aan de werkzaamheden. De loonwerker zal de } \\
\text { meerkosten willen doorbelasten. }\end{array}$ \\
\hline Vrijwillige afspraak (ja/nee) & Zie stimulering \\
\hline
\end{tabular}

\section{Toelichting maatregel}

Na de introductie van zodenbemesting begin jaren ' 90 is er een trend over de jaren vastgesteld waarbij de ammoniakemissie bij zodenbemesting is gestegen (Huijsmans \& Schils, 2009). Deze hogere emissie is mogelijk te verklaren door een andere uitwerking/toepassing van zodenbemesting in de praktijk. Hierbij valt o.a. te denken aan minder diep werken (meer richting sleufkouter), zodat minder trekkracht gevraagd wordt en daarmee de capaciteit van de machine kan stijgen of brandstof kan worden bespaard. Verondersteld wordt dat weer een lager niveau voor de emissie bereikt kan worden door een goede werking (o.a. door afstelling), waarbij alle mest goed in sleuven wordt toegediend. De effectiviteit van deze maatregel is mogelijk afhankelijk van de grondsoort. Hier is een emissiereductie ingeschat van $25 \%$, waarbij dit leidt tot een emissie van $14 \%$ bij zodenbemesting (nog verder te onderbouwen).

\section{Toelichting praktische implementatie}

Aandacht voor goede werking zodenbemesting is momenteel op de achtergrond gekomen, omdat minder diep werken ook veelal geaccepteerd is. Het aspect "alle mest goed in sleuven" moet weer onder de aandacht gebracht worden. Dit kan mogelijk ook leiden tot een schifting van te gebruiken machines (sommige machines worden "zodenbemester" genoemd terwijl het te realiseren werkresultaat hiermee niet overeenkomt). Voorlichting, borging/handhaving, keuring machines, opleiding chauffeurs etc. zijn aspecten om de effectiviteit van de mesttoediening te verhogen. Daarnaast zijn er mogelijkheden om technieken toe te passen die de goede werking monitoren.

\section{Toelichting kosten}

Aangenomen wordt dat de meerkosten $€ 0,50$ per m3 mest zijn. De meeste kosten zitten in extra arbeid.

In Nederland wordt 60 miljoen ton dierlijke mest uitgereden op 1 miljoen ha grasland. 60 miljoen ton $* € 0,50$ per ton $=€ 30$ miljoen per jaar. Als in $202030 \%$ geïmplementeerd is, dan dus $30 \%$ van deze bedragen.

Een loonwerker rijdt $30 \mathrm{~m} 3$ mest per uur uit; $250 \mathrm{~m} 3$ per dag. Dit gedurende 120 dagen in het jaar, maakt $30.000 \mathrm{~m} 3$ per combinatie. Stel aanpassing machine geeft investering $€ 15.000$, dan is dat $€$ 0,50 per $\mathrm{m} 3$. 


\subsubsection{Factsheet 11. Emissiebeperkende weersomstandigheden}

\section{Emissiebeperkende weersomstandigheden}

Gebruik maken van de voorspelbaarheid van lokale weersomstandigheden en de lokale mesttoediening afstemmen op emissiearme weerscondities. Data uitrijverbod (weersomstandigheden); differentiatie naar grondsoort.

Weersomstandigheden kort na uitrijden en aansluitende dagen spelen een rol bij de hoogte van de optredende emissie. Inspelen op deze weersomstandigheden betekent inpassing in andere werkzaamheden, vragen over beschikbare capaciteit (loonwerker), toelaatbare bodemcondities en gewasstadium.

Hier liggen mogelijke eerste opties voor mesttoediening op grasland.

Uitgegaan wordt van een emissiereductie van $25 \%$ bij zodenbemesting (ten opzichte van huidige emissiefactor van 19\%). In de berekeningen is uitgegaan van een emissiefactor van $14 \%$ voor zodenbemesting

(Mogelijk straks nog wel onderscheid naar grondsoort)

\begin{tabular}{|l|l}
\hline Effectiviteit reductie & 2030
\end{tabular}

Bij landelijke maatregel: emissiedaling (kton $\mathrm{N} / \mathrm{jr}$ )

6,1

\section{Implementatie (kosteneffectiviteit en tijdpad)}

Kosteneffectiviteit ( $\mathrm{M} € /$ kton $\mathrm{N}$ ) Investeringskosten voor de sector (M€)

Operationele kosten voor de sector $(\mathrm{M} € / \mathrm{jr})$

Tijd benodigd voor invoering maatregel (jr) Termijn waarop effect wordt bereikt (jr)

\section{Afdwingbaarheid en instrumentatie}

Verplicht in te voeren via wet- en regelgeving (ja/nee)

Vrijwillig in te voeren via kennisdeling en stimulering ( $\mathrm{ja} / \mathrm{nee})$

Vrijwillige afspraak (ja/nee)

\section{0}

4,4

160

27

5-10 jaar

\section{5-10 jaar}

Mogelijk moeilijk te borgen

Veel zal afhangen van arbeidsfilm op het bedrijf, van de loonwerker en of er goede omstandigheden zijn te vinden als de mest op het veld gewenst is.

Zie stimulering

\section{Toelichting maatregel}

De weersomstandigheden kort na uitrijden en aansluitende dagen (temperatuur en windsnelheid) spelen een rol bij de hoogte van de optredende ammoniakemissie (Huijsmans et al., 2001; Søgaard et al., 2002). Inspelen op deze weersomstandigheden bij het uitrijden op basis van voorspelbaarheid kan bijdragen aan het verminderen van de emissie. Op basis van een paar eerste modelberekeningen lijkt een emissiereductie van $25 \%$ bij zodenbemesting mogelijk.

\section{Toelichting praktische implementatie}

Met de mesttoediening inspelen op emissiebeperkende weersomstandigheden betekent ook inpassing in andere werkzaamheden, vragen over beschikbare capaciteit (loonwerker), toelaatbare bodemcondities en gewasstadium bij die weersomstandigheden. Inspelen op de weersomstandigheden betekent in ieder geval dus vragen om flexibiliteit om het werk uit te voeren en een grotere beschikbare machinecapaciteit. Daarnaast vergt dit een andere aanpak voor de handhaving/borging. 


\section{Toelichting kosten}

Weersomstandigheden: mikken op goede weersomstandigheden zal betekenen dat capaciteit voor mest uitrijden misschien wel meer dan verdubbeld moet worden om tijdig de mest uit te kunnen rijden binnen een areaal en dientengevolge hogere kosten.

In Nederland wordt 60 miljoen ton dierlijke mest uitgereden op 1 miljoen ha grasland.

Als per combinatie $30.000 \mathrm{~m} 3$ per jaar wordt gedaan, dan zijn er 2.000 combinaties nodig. Als dit moet verdubbelen en de investering per combinatie is $€ 80.000$ (100\% extra zodenbemesters, 50\% extra tractoren), dan totale investering $€ 160$ miljoen. Jaarkosten hiervan zijn $€ 27$ miljoen. Als in $202020 \%$ geïmplementeerd is, dan dus $20 \%$ van deze bedragen. 


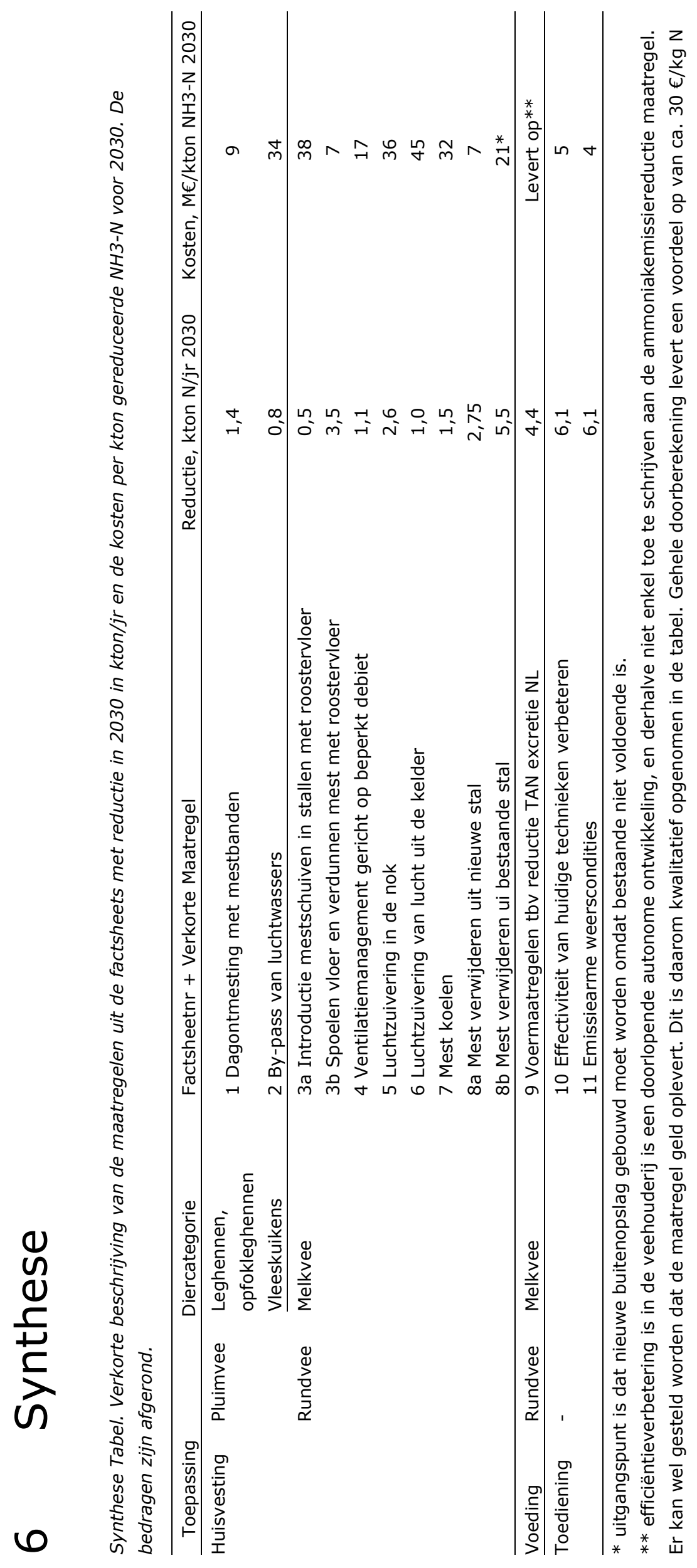




\section{Literatuur}

Ellen, H.H., C.M. Groenestein, N.W.M. Ogink , 2017. Actualisering ammoniak emissiefactoren pluimvee; Advies voor aanpassing van ammoniak emissiefactoren van pluimvee in de Regeling ammoniak en veehouderij (Rav). Wageningen Livestock Research, Rapport 1015 - 60 p.

Groenestein, K., Bikker, P., Bruggen, van C., Ellen, H., Harn van, J., Huijsmans, J., Ogink, N., Şebek, L. en I. Vermeij, 2017. PAS Aanvullende reservemaatregelen Landbouw: uitwerking van een Quick scan. Wageningen Livestock Research, Rapport 1145 - 53 p.

Groenestein, C.M. en J.W.H. Huis in't Veld, 1996. Praktijkonderzoek naar de ammoniakemissie van stallen XXVII. Vleesvarkensstal met koeling van mestoppervlak in de kelder. Wageningen, DLO Rapport 96-1003 - 15 p.

Huijsmans, J.F.M. \& R.L.M. Schils (2009). Ammonia and nitrous oxide emissions following fieldapplication of manure: state of art measurements in the Netherlands. Proceedings 655, International Fertiliser Society, $35 \mathrm{pp}$.

Huijsmans, J. F. M., Hol, J. M. G. \& Hendriks, M. M. W. B., 2001, Effect of application technique and external factors on ammonia volatilisation from manure applied to grassland. In: RAMIRAN Proceedings of the 9th International Workshop of the Network, Gargnano, University of Milan, (SP.) 6-9 September. p. 357-360

Søgaard, H.T., S.G. Sommer, N.J. Hutchings, J.F.M. Huijsmans, D.W. Bussink and F. Nicholson, 2002. Ammonia volatilization from field-applied animal slurry-the ALFAM model. Atmospheric Environment 36 (20): 3309-3319.

Winkel, A. ; Ellen, H.H. ; Ogink, N.W.M. (2014) Mogelijkheden voor het vaststellen van emissies van leghennenstallen met een nageschakeld mestdroogsysteem $=$ Possibilities for determining emissions of laying hen houses connected to a manure drying system. Lelystad : Wageningen UR Livestock Research, (Report / Wageningen UR Livestock Research 803) - 20 p. 


\section{Bijlage 1 Referentiesystemen t.b.v. behoeve van ammoniakemissie- reductie berekening van Facsheet 1: Dagontmesting met mestbandsystemen}

De referentie voor volière- en kooisystemen is $1 \mathrm{x}$ per week afdraaien van beluchte mest. Dit systeem kent geen referentie voor grondhuisvesting omdat hier geen of nauwelijks sprake is van mestbanden. Bovendien neemt aandeel grondhuisvesting naar verwachting af. Er zijn 5 volièresystemen voor leghennen (E 2.11.1, E 2.11.2.1; E 2.11.2.2; E 2.11.3; E 2.11.4) en 6 voor opfokleghennen (E 1.8.1, $E$ 1.8.2; E 1.8.3.1; E 1.8.3.2; E 1.8.4; E 1.8.5) die als referentie dienen voor volièrestallen. Volgens Winkel etal., 2014 (rapport 803) is een ammoniakemissiereductie van $30 \%$ mogelijk bij dagontmesting in een voliérestal.

Voor de kooisystemen voor leghennen met 1xper week afdraaien en beluchting zijn er 2 referenties ( $E$ 2.5.5 en E 2.5.6). Voor kooihuisvesting is de reductie hoger omdat alle mest via de band verwijderd wordt en er geen strooisel in de stal is. De reductie is voor kooihuisvesting derhalve geschat op 55\% (Winkel etal., 2014).

Tabel 1 geeft een reele schatting van de implementatie van huisvestingssystemen in 2012-2014 en een inschatting van de implementatie voor 2020 en 2030 afhankelijk van de tijd die nodig is voor de invoering van de maatregel

Tabel 1 Aandeel van leghennen en opfokleghennen in volièrehuisvesting, kooihuisvesting en grondhuisvesting met en zonder droogtunnel voor de referentiejaren 2012-2014, 2020 en 2030.

\begin{tabular}{|l|l|l|c|c|c|}
\hline & & & $2012-2014$ & 2020 & 2030 \\
\hline Leghennen & volière & Droogtunnel & 0.15 & 0.35 & 0.85 \\
\hline & & Geen droogtunnel & 0.45 & 0.35 & 0.15 \\
\hline & kooi & Droogtunnel & 0.05 & 0.1 & 0 \\
\hline & & Geen droogtunnel & 0.15 & 0.1 & 0.85 \\
\hline & grond & & 0.2 & 0.1 & 0.15 \\
\hline & volière & Droogtunnel & 0.15 & 0.35 & 0.35 \\
\hline & & Geen droogtunnel & 0.45 & 0.1 & 0.1 \\
\hline
\end{tabular}

De investeringskosten zijn berekend ervan uitgaande dat droogtunnels in 2012-2014 al bij 20\% van de dieren geïmplementeerd is. Dat betekent dat $80 \%$ van de dieren nog voorzien moeten worden van een droogtunnel. Tot 2020 is de verwachting dat deze ontwikkeling autonoom en onder invloed van het huidige Besluit emissiearme huisvesting verloopt. Voor de overige $55 \%$ zal naar verwachting een stimuleringsregeling nodig zijn. Voor de $20 \%$ van de dieren van wie de mest al met een droogtunnel gedroogd wordt zijn geen extra kosten van toepassing (het meerdere keren afdraaien van de banden kost een verwaarloosbare hoeveelheid energie, ook het extra energieverbruik van de droogtunnel kan verwaarloosd worden (Ellen, persoonlijke mededeling) 


\title{
Bijlage 2 Achtergrondinformatie bij Factsheet 9: TAN-excretie verminderen op het melkveebedrijf met voermaatregelen
}

\begin{abstract}
Achtergrond
De bron van ammoniakemissie op een veehouderijbedrijf is de hoeveelheid ammoniakaal stikstof (TAN in $\mathrm{kg}$ per jaar) die door de veestapel wordt geproduceerd. Een effectieve maatregel om de ammoniakemissie te verlagen is dan ook het verlagen van de TAN-excretie door de veestapel. Toepassen van deze doelmaatregel gebeurt via het voer- en diermanagement en is daarmee een pakket van maatregelen. Vrijwel ieder Nederlands melkveebedrijf kan in dat pakket passende maatregelen vinden. Het gaat daarbij niet om de toepassing van afzonderlijke voermaatregelen, maar om de combinatie van maatregelen.

Uitvoering van deze maatregelen kan alleen als de melkveehouder goede informatie krijgt over de gerealiseerde TAN-excretie. De module Bedrijfsspecifieke Emissie Ammoniak (BEA) van de Kringloopwijzer is een methodiek waarmee voor een melkveebedrijf de gerealiseerde TAN-excretie vastgesteld kan worden.
\end{abstract}

\section{Inschatten effect van het verlagen van de TAN-excretie op het melkveebedrijf}

De reductiemogelijkheden voor de TAN-excretie kunnen met enkele kengetallen worden ingeschat. Door voor die kengetallen een in de praktijk haalbare uiterste waarde (maximum dan wel minimum) te definiëren en die te vergelijken met de actuele waarde (Tabel 1) wordt duidelijk wat de geschatte reductiepotentie in $\mathrm{kg}$ TAN is. De gemiddelde NL waarde van kengetallen is gebaseerd op data van de WUM en voor 2019 is die referentie gelijk aan het gemiddelde van de jaren 2015, 2016 en 2017 zoals vastgesteld door de WUM. Vervolgens is voor de kengetallen een uiterste waarde ingeschat (let op: op basis van expert judgement en dat zou breder getoetst kunnen/moeten worden)

Tabel 1 Kengetallen TAN-excretie van melkvee op basis van WUM, inclusief ontwikkeling van 1990-2017 en minimale dan wel maximale waarden (ingeschat).

\begin{tabular}{|c|c|c|c|c|c|c|c|}
\hline \multirow{2}{*}{ nr } & \multirow{2}{*}{$\begin{array}{l}\text { Regio } \\
\text { Kengetal }\end{array}$} & \multicolumn{2}{|c|}{ NL } & \multicolumn{2}{|c|}{ NW } & \multicolumn{2}{|c|}{ zo } \\
\hline & & 1990 & 2017 & $\max$ & $\min$ & Max & $\min$ \\
\hline 1 & $\begin{array}{l}\text { Verteringscoëfficiënt ruw eiwit } \\
\text { (VC-re in \%) }\end{array}$ & 80,1 & 69,1 & - & 62,5 & - & 62,5 \\
\hline 2 & $\begin{array}{l}\text { Ruwe eiwitgehalte rantsoen } \\
\text { (g re/kg droge stof) }\end{array}$ & 202,1 & 161,9 & - & 145 & - & 140 \\
\hline 3 & $\begin{array}{l}\text { Voeropname } \\
\text { (in kg per dier per dag) }\end{array}$ & 15,2 & 19,4 & - & - & - & - \\
\hline 4 & $\begin{array}{l}\text { Melkproductie } \\
\text { (kg FPCM }{ }^{1} \text { per dier per jaar) }\end{array}$ & 6300 & 8937 & 10000 & - & 11000 & - \\
\hline 5 & $\begin{array}{l}\text { Voerefficiëntie } \\
\text { (kg FPCM }{ }^{1} \text { per kg opgenomen droge stof) }\end{array}$ & 1,085 & 1,264 & 1,4 & - & 1,5 & - \\
\hline 6 & $\begin{array}{l}\mathrm{N} \text {-benutting } \\
(\mathrm{N} \text { in melk/opgenomen verteerbare } \mathrm{N} \text {, in \%) }\end{array}$ & 24,1 & 38,1 & 45,0 & - & 50,0 & - \\
\hline 7 & $\begin{array}{l}\mathrm{N} \text {-efficiëntie } \\
(\mathrm{N} \text { in melk / opgenomen } \mathrm{N} \text {, in \%) }\end{array}$ & 19,3 & 26,3 & 35,0 & - & 35,0 & - \\
\hline
\end{tabular}


Tabel 1 is ten opzichte van de vorige rapportage (Groenestein e.a. 2017, WLR rapport 1145) ongewijzigd gebleven met uitzondering van de update naar de actuele situatie (van 2014 naar 2017). Een belangrijk verschil is de gewijzigde berekeningswijze voor TAN (conform aanpassing Nema) die zich in dit verband uit in de berekende VC-re. Conform Bannink e.a., 2016 ${ }^{2}$ is VC-re in de nieuwe rekenwijze gemiddeld $7,5 \%$ eenheden lager. In tabel 1 is daarom de minimale VC-re aangepast van $70 \%$ naar $62,5 \%$.

Vervolgens is ingeschat of en, zo ja hoe, die kengetallen zich gaan ontwikkelen naar de ingeschatte uiterste waarden en dan met name voor 2020 en 2030. De aangenomen ontwikkeling is in principe een extrapolatie van de ontwikkeling van die kengetallen in de periode 1990-2017 (op basis van WUM), maar de extrapolatie heeft als eindpunt de ingeschatte uiterste waarde (minimum dan wel maximum). Vervolgens is met die informatie de TAN-excretie voor zowel de huidige situatie (gemiddelde over 2015-2017) als de jaren 2020 en 2030 doorgerekend (Tabel 2). Het verschil tussen de basis TAN-excretie (benchmark) en de prognose voor 2020 en 2030 geeft dan de potentiële emissiereductie voor de maatregel 'verminderen TAN-excretie'.

Tabel 2 Berekende kengetallen en TAN-excretie van melkgevende koeien voor de referentie (benchmark) en voor de jaren 2020 en 2030 na het nemen van voermaatregelen.

\begin{tabular}{|c|c|c|c|c|c|c|c|c|c|c|}
\hline & & & & & \multicolumn{5}{|c|}{ Per dier per dag } & \\
\hline & & & $\mathrm{g} / \mathrm{kg}$ ds & $\mathrm{kg} / \mathrm{jaar}$ & & kg & & & gram & \\
\hline & & VC_re & RE rants & FPCM & voereff & DSopn & Neff & Nbenut & TANtot & \\
\hline & & & & & & & & & & \\
\hline \multicolumn{11}{|l|}{ Benchmark } \\
\hline gemiddeld & $0+\mathrm{Z}$ & 0,715 & 149,3 & 8606 & 1,30 & 18,1 & 0,295 & 0,412 & 194,0 & \\
\hline \multirow[t]{2}{*}{ 2012-2014 } & $\mathrm{N}+\mathrm{W}$ & 0,754 & 171,7 & 8274 & 1,26 & 18,1 & 0,247 & 0,328 & 263,3 & \\
\hline & $\mathrm{NL}$ & 0,732 & 158,5 & 8453 & 1,28 & 18,1 & 0,273 & 0,373 & 222,8 & \\
\hline gemiddeld & $O+Z$ & 0,684 & 155,6 & 9105 & 1,28 & 19,5 & 0,277 & 0,404 & 213,6 & \\
\hline \multirow[t]{4}{*}{ 2015-2017 } & $\mathrm{N}+\mathrm{W}$ & 0,699 & 170,8 & 8698 & 1,25 & 19,1 & 0,246 & 0,352 & 252,5 & \\
\hline & $\mathrm{NL}$ & 0,691 & 161,9 & 8937 & 1,26 & 19,4 & 0,263 & 0,381 & 230,0 & \\
\hline & & & & & & & & & & reductie \\
\hline & & & & & & & & & & tov benchmark \\
\hline \multirow{3}{*}{2020} & $O+Z$ & 0,676 & 150,4 & 9491 & 1,31 & 19,9 & 0,292 & 0,433 & 199,1 & 0,026 \\
\hline & $\mathrm{N}+\mathrm{W}$ & 0,691 & 165,6 & 9067 & 1,27 & 19,5 & 0,259 & 0,376 & 238,8 & $-0,093$ \\
\hline & $\mathrm{NL}$ & 0,683 & 156,6 & 9316 & 1,29 & 19,7 & 0,278 & 0,407 & 215,9 & $-0,031$ \\
\hline \multirow{3}{*}{2030} & $\mathrm{O}+\mathrm{Z}$ & 0,641 & 140,0 & 11000 & 1,34 & 22,5 & 0,321 & 0,500 & 179,2 & $-0,077$ \\
\hline & $\mathrm{N}+\mathrm{W}$ & 0,656 & 145,0 & 10000 & 1,27 & 21,5 & 0,295 & 0,450 & 197,3 & $-0,251$ \\
\hline & $\mathrm{NL}$ & 0,648 & 142,3 & 10542 & 1,31 & 22,0 & 0,309 & 0,477 & 187,7 & $-0,158$ \\
\hline
\end{tabular}

Uit Tabel 2 blijkt dat er met voermaatregelen voor de melkveestapel een reductie van de ammoniakemissie mogelijk is ten opzichte van 2012-2014 van ca 3\% in 2020 en ca $16 \%$ in 2030 . Tot 2020 wordt voor de regio Zuid-Oost een toename van 2,6\% in TAN-excretie geschat en voor de regio Noord-West een reductie van 9,3\%. Tot 2030 wordt voor de regio Zuid-Oost een reductie van $7,7 \%$ in TAN-excretie geschat en voor de regio Noord-West een reductie van $25,1 \%$. De reden voor de grotere reductiepotentie in de regio Noord-West is dat bij de gevolgde uitgangspunten (de min en max in tabel 1) de regio Zuid-Oost bij extrapolatie van de trend 1990-2017 eerder een uiterste randvoorwaarde bereikt. Voor die regio wordt dus eerder de maximale reductiepotentie gerealiseerd. De kengetallen waar die uiterste waarde voor wordt bereikt zijn het re-gehalte in het rantsoen en de VC-re.

Ten opzichte van de schatting van de ontwikkelingen door Groenestein e.a. (2017) blijkt dat het effect van de aanpassing in de NEMA-berekening door een verlaging van de VC-re gecompenseerd wordt door een grotere toename van de melkproductie (en een daarmee samenhangende hogere voeropname) dan verwacht. Daarnaast heeft de verwachtte daling van het re-gehalte in het rantsoen niet plaatsgevonden, maar bleek het een lichte stijging te hebben doorgemaakt. Tot slot is de VC-re met ca. 3 procenteenheden gestegen, maar die ontwikkeling is in tabel 2 'onzichtbaar' vanwege de aanpassing in de NEMA berekening met een gemiddeld 7,5\% lagere VC-re.

\footnotetext{
${ }^{2}$ Bannink, A., L. Šebek, J. Dijkstra, 2016. Evaluatie berekening VC_RE in NEMA 2015. Wageningen Livestock Research, Vertrouwelijk Rapport 465.
} 


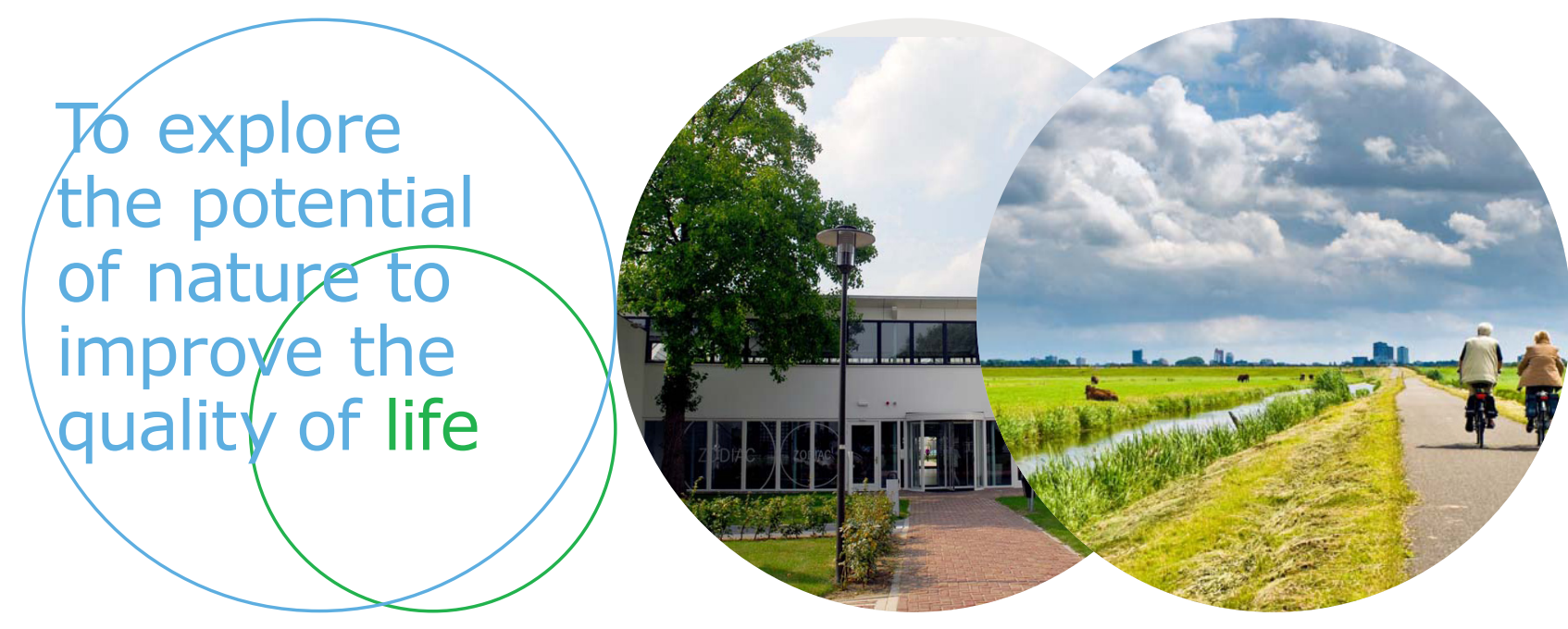

Wageningen Livestock Research Postbus 338

Wageningen Livestock Research ontwikkelt kennis voor een zorgvuldige en $6700 \mathrm{AH}$ Wageningen

T 0317483953

renderende veehouderij, vertaalt deze naar praktijkgerichte oplossingen en innovaties, en zorgt voor doorstroming van deze kennis. Onze wetenschappelijke E info.livestockresearch@wur.nl www.wur.nl/ livestock-research kennis op het gebied van veehouderijsystemen en van voeding, genetica, welzijn en milieu-impact van landbouwhuisdieren integreren we, samen met onze klanten, tot veehouderijconcepten voor de 21 e eeuw.

De missie van Wageningen University \& Research is 'To explore the potential of nature to improve the quality of life'. Binnen Wageningen University \& Research bundelen 9 gespecialiseerde onderzoeksinstituten van Stichting Wageningen Research en Wageningen University hun krachten om bij te dragen aan de oplossing van belangrijke vragen in het domein van gezonde voeding en leefomgeving. Met ongeveer 30 vestigingen, 6.500 medewerkers en 10.000 studenten behoort Wageningen University \& Research wereldwijd tot de aansprekende kennisinstellingen binnen haar domein. De integrale benadering van de vraagstukken en de samenwerking tussen verschillende disciplines vormen het hart van de unieke Wageningen aanpak. 